
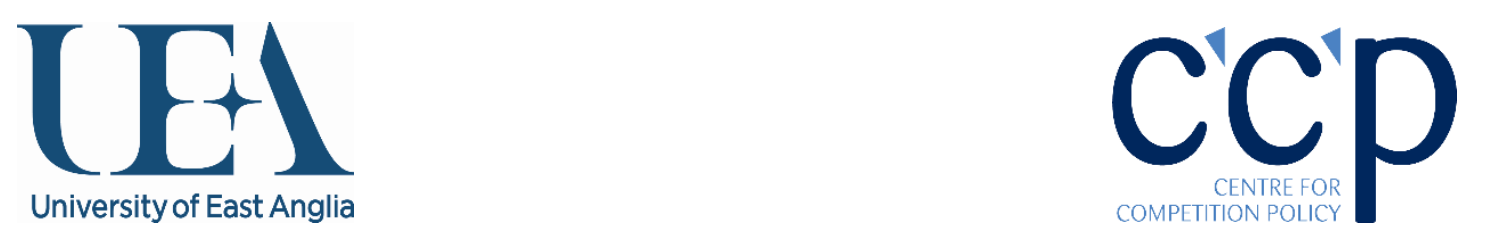

\title{
The History and Scope of EU Health Law and Policy
}

\author{
Mary Guy \\ Centre for Competition Policy \\ UEA Law School \\ University of East Anglia \\ Wolf Sauter \\ Tilburg Centre for Law and Economics (TILEC), Tilburg University \\ Dutch Healthcare Authority (NZa) \\ Authority for Consumers and Markets (ACM)
}

\section{CCP Working Paper 16-2}

\begin{abstract}
This paper looks at the origins and limits of EU health law and policy. The main questions asked are whether EU health law is expanding and how; whether it operates within fixed limits; and whether healthcare is a special case in EU integration. Special attention is paid to the emergence of a specific legal basis in Article 168 TFEU alongside the general internal market provisions of the EU, and its sector-specific subsidiarity provision which suggests healthcare was at least intended to be a special case: a policy largely reserved to the national level. In practice however the EU competence in this field is expanding not only as a matter of negative integration (striking down conflicting national rules to promote the internal market), but also in terms of cooperation between the Member States. Finally the recent impact of general financial curbs on the welfare State (such as are imposed in the context of the European semester) show that in spite of national efforts to retain control over healthcare, such control is in fact steadily eroded. The result is less the emergence of a unified EU policy than a complex system of partial overlapping national and EU competences that may come both come into conflict and complement each other.
\end{abstract}

Contact Details:

Mary Guy

mary.guy@uea.ac.uk 


\title{
The History and Scope of EU Health Law and Policy
}

\author{
Mary Guy and Wolf Sauter*
}

\begin{abstract}
This paper looks at the origins and limits of EU health law and policy. The main questions asked are whether EU health law is expanding and how; whether it operates within fixed limits; and whether healthcare is a special case in EU integration. Special attention is paid to the emergence of a specific legal basis in Article 168 TFEU alongside the general internal market provisions of the EU, and its sector-specific subsidiarity provision which suggests healthcare was at least intended to be a special case: a policy largely reserved to the national level. In practice however the EU competence in this field is expanding not only as a matter of negative integration (striking down conflicting national rules to promote the internal market), but also in terms of cooperation between the Member States. Finally the recent impact of general financial curbs on the welfare State (such as are imposed in the context of the European semester) show that in spite of national efforts to retain control over healthcare, such control is in fact steadily eroded. The result is less the emergence of a unified EU policy than a complex system of partial overlapping national and EU competences that may come both come into conflict and complement each other.
\end{abstract}

Key words: healthcare; public health; subsidiarity; European integration; governance. JEL codes: I1; I18; K2; K32.

\section{Introduction}

In this contribution we will set out the history and scope of European Union (EU) health law and policy in general terms. It provides an overview that is intended to facilitate a more substantial specialised discussion of particular topics - such as the role of EU Courts and patient mobility, or competition in healthcare. The main question that is asked here is: where did EU health competence and policies come from and what is their reach today? In the course of addressing this question we will briefly look not just at the background of EU policies but also at the different types of legal basis and governance instruments involved. Secondary questions that we will examine are:

- Is the competence of the EU in the area of health law and policy expanding, and if so, in which directions?

- Are there clear and fixed limits to its scope?

- Is the development of healthcare law and policy a special case and to what extent do general trends in EU integration play a role here?

To answer these questions we will rely to a large extent on the pre-existing literature in the field of EU healthcare law and policy. ${ }^{1}$ Finally we will also try to highlight specific trends that are relevant to more detailed further discussion.

\footnotetext{
${ }^{*}$ Mary Guy is affiliated with UEA Law School and the Centre for Competition Policy (CCP) at the University of East Anglia. Wolf Sauter is affiliated with the Tilburg Centre for Law and Economics (TILEC) at Tilburg University, works for the Dutch Healthcare Authority (NZa) and is currently on secondment to the Authority for Consumers and Markets (ACM). The opinions presented here are personal.

${ }^{1}$ E.g. T.K. Hervey and J.V. McHale, European Union Health Law - Themes and Implications (Cambridge University Press 2015); S.L. Greer, N. Fahy, H.A. Eliott, M. Wismar, H. Jarman and W. Palm, Everything you always wanted to know about European Union health policies but were afraid to ask (European Obesrvatory on health systems and policies, Brussels 2014); S.L.Greer, T.K. Hervey, J.P. Mackenbach and M. McKee, Health law and policy in the European Union', The Lancet 381 (2013) 1135-1143; E.
} 


\section{History}

\section{European integration in general terms}

The EU is an international organisation that was originally founded as the European Economic Community (EEC) by six Member States based on the Rome Treaty of 1957. It was preceded by the European Community on Coal and Steel (ECSC Treaty 1951), which was a sectoral initiative, and the Benelux (1944) with a more restricted membership. The objective of these various Treaties was to ensure future peaceful relations between their members, as well as post-World War II reconstruction and economic development. The main instrument to this effect within the EEC was free trade between the Member States within the common market (now: the internal market) but within common external boundaries. ${ }^{2}$ At a global level, the EEC system of regional preference was allowed as an exception to the General Agreement on Tariffs and Trade, or GATT, which came into effect in 1948 and to which the EEC Member States also subscribed.

The original governance system of the EEC was based (i) on legislation by the Council of Ministers representing the Member States, (ii) on the European Commission, an executive body with a professional staff organized in various directorates general, as well as (iii) on a European Court of Justice to adjudicate EU law issues. The latter two bodies acted independently from national interests. In 1962 a European Parliament was added that was first elected by universal suffrage in 1979 and has since evolved into a full-fledged colegislature. Further institutions that were added are a Court of Auditors and a Court of First Instance (now the General Court, formally part of the Court of Justice of the EU) as well as the European Central Bank and the European Council of heads of state and government (granting the status of EU institution to what had originated as a special session of the Council of Ministers). These institutions are listed in Article 13 of the Treaty on European Union (TEU).

For the various policies of the EU a structure of expert committees representing the Member States has emerged to assist in the adoption of technical regulations, as well as various independent agencies and other administrative bodies. The main agencies that are active in the realm of healthcare include the European Centre for Disease Control and Prevention (ECDC, 2005), the European Medicines Agency (EMA, 1993), the European Monitoring Centre for Drugs and Drug Addiction (1995), the European Environment Agency (1993) and the European Agency for Health and Safety at Work (1994). ${ }^{3}$

The internal market forms the original foundation of European integration and continues to play a pivotal role. It is based on the free movement of goods, services, persons (starting with workers, and including establishment) and capital (including payments). At the outset of the EEC there was nothing in the relevant Treaty provisions that indicated healthcare would be included. Although the healthcare sector was not explicitly excluded

Mossialos, G. Permanand, R. Baeten and T.K. Hervey, Health systems governance in Europe: the role of European Union law and policy (Cambridge University Press, 2010).

${ }^{2}$ Article 2 EEC read: It shall be the aim of the Community, by establishing a Common Market and progressively approximating the economic policies of Member States, to promote throughout the Community a harmonious development of economic activities, a continuous and balanced expansion, an increased stability, an accelerated raising of the standard of living and closer relations between its Member States.

${ }^{3}$ Greer et al. above n. 1. M. Everson, C. Monda and C. Vos, E. (Eds.), European agencies in between institutions and Member States (Kluwer Law International, Alphen aan den Rijn 2014). 
either, the EEC (and later EU) system of limited competencies mean that in the absence of a positive provision the existence of a competence could not be assumed. As we will see this position has gradually changed: over time health issues have been brought under the market freedoms. New provisions assigning EU competencies on healthcare have also been created, and secondary legislation has been adopted. Initially this occurred in the area of social security rights for (frontier) workers, ${ }^{4}$ but subsequently more broadly to cover all EU nationals ${ }^{5}$ respectively all patients with rights to treatment in the Member States.

At the same time the general scope of the EEC, then the EC (European Community) and now the EU has broadened to include notably citizenship, but also a common foreign and security policy, policies on security and criminal justice, coordination of economic polies, and for 18 of its Members a common currency, the Euro. In all these areas a degree of sovereignty has been surrendered by the Member States to the EU. This means that, increasingly, the EU no longer resembles an international organization but has become a confederation, or even an entity with federal traits. This process is thought to be expressed by the aspiration toward 'ever closer Union' originally set out in the preamble to the Rome Treaty that today is found in Article 1 of the Treaty on European Union (TEU, 2007).

However the degree to which this development is desirable remains strongly contested and the explicit reference to federalism in the draft constitutional treaty of $2004^{6}$ can be seen as one of the raisons why it failed in two national referenda in 2005 and was replaced by the less ambitious Lisbon Treaty (2007, comprising the TEU and the Treaty on the Functioning of the European Union, TFEU) which entered into force in December 2009. Treaty change, although important for setting the general legal and constitutional framework, is not the only or even the main factor that determines the development of EU policies. Secondary legislation (Regulations and Directives) based on general competencies such as that to promote the internal market in Article 114 TFEU also play a role. Most importantly, the interpretation of existing EU law by the Court of Justice of the EU (or CJEU, a term that captures both the General Court and the Court of Justice) plays a significant part.

The CJEU has discovered, developed and enforced the direct effect and supremacy of EU law. The former means EU law can thereby be invoked before national courts, giving them an important role in applying and enforcing EU law over and against conflicting national rules. Supremacy means EU law trumps national law. This judicial process has been criticized for eroding national welfare states $^{7}$ by enforcing free trade and

\footnotetext{
${ }^{4}$ Règlement $\mathrm{n}^{\circ} 3$ concernant la sécurité sociale des travailleurs migrants, OJ 30 of 16 December 1958. Subsequently Council Regulation (EEC) No 1408/71 of 14 June 1971 on the application of social security schemes to employed persons, to self-employed persons and to members of their families moving within the Community, OJ 1971, L149/2.

${ }^{5}$ Regulation (EC) No 883/2004 of the European Parliament and of the Council of 29 April 2004 on the coordination of social security systems, OJ 2004, L166/1. See F. Pennings, European social security law, $5^{\text {th }}$ edn. (Intersentia, Antwerp 2010).

${ }^{6}$ Treaty establishing a Constitution for Europe as signed in Rome on 29 October 2004, OJ 2004, C310/1.

${ }^{7}$ In healthcare: see e.g. V.G. Hatzopoulos, 'Killing National Health and Insurance Systems but healing Patients? The European Market for Health Care Services After the Judgments of the ECJ in Vanbraekel and Peerbooms', Common Market Law Review 39 (2002) 683-729; Anthony Dawes, 'Bonjour Herr Doctor': National Healthcare Systems, the Internal Market and Cross-border Medical Care within the European Union', Legal Issues of Economic Integration 33 (2006) 167-182; G.T. Davies, 'The community's internal
} 
competition - negative integration - even in a context where there is no equivalent scope for positive integration, or the formulation of new EU policies to replace national policies. This lopsided ability to act positively has been called a 'constitutional asymmetry'. ${ }^{8}$ As a result it is sometimes thought that in the EU liberal market oriented policies focusing on the interest of the individual will always prevail over policies based on solidarity and sharing. Finally because EU law has direct effect in the Member States individuals may bring actions based on EU law provisions and principles even against the Member States in national courts. This greatly enhances the effectiveness of EU law and such actions are at the origin of many of the decisions of EU and national courts that were just discussed.

Although in the remainder of this contribution we will not address these aspects in greater detail they do provide an institutional context of ever closer cooperation that has also had an impact on the history and scope of EU healthcare law and policy.

\section{EU integration and the special characteristics of healthcare}

Today the EU is composed of 28 Member States, each with a national healthcare system. There is a wide variety of such systems at national level but in general terms we can distinguish between on the one hand insurance based so-called Bismarck systems, which may have private or public provision of care or a combination of both, and on the other hand tax-based national health services or Beveridge systems, which are more likely to have public provision but may in part rely on private provision of care (as well as supplementary private insurance). Both Bismarck and Beveridge systems share cost constraints and concerns about the affordability of care in the face of ageing populations, technological developments and rising expectations. They also share the market failures that are typical of healthcare: asymmetrical information, externalities, moral hazard and public goods. Hence while the healthcare systems in the EU remain divided by important differences in organization, they are similar regarding the problems they face.

If we assume that a healthcare system assigns access rights to healthcare to a particular target population and ensures the organization, notably the funding and delivery of such care the EU cannot be said to have its own healthcare system separately from the abovementioned national healthcare systems of the Member States. Instead it disposes of a number of fairly fragmented but complementary competencies and is responsible for a number of policies that affect the healthcare systems of the Member States either directly or indirectly without itself forming an EU healthcare system as such. Some EU instruments are specifically intended that way, such as the mutual recognition of medical qualifications enabling cross-border establishment of medical professionals and promoting the internal market. ${ }^{9}$ Others are merely the effect of general EU rules, such as the effect of freedom of establishment on planning rules for the spatial distribution of pharmacists. These EU competencies, their scope and impact have been characterized by a gradual expansion. This is why we will briefly look at two examples of how healthcare competencies expanded beyond their internal market origins, as well as the development of the specific public health provision, Article 168 TFEU.

\section{The history of Article 168 TFEU}

market-based competence to regulate healthcare: scope, strategies and consequences', Maastricht Journal of European and Comparative law14 (2007) 215-238.

${ }^{8}$ F. Scharpf, 'The European social model: coping with the challenges of diversity', Journal of Common Market Studies 40 (2002) 645-70.

${ }^{9}$ Directive 2005/36/EC of the European Parliament and of the Council of 7 September 2005 on the recognition of professional qualifications, OJ 2005, L255/22. 
Despite the absence of references to health in the founding Treaties of the 1950s, there have been health-related provisions encompassing coordination of social security systems, ensuring access to healthcare for migrant workers moving between Member States and a strong role in improving health in areas such as the environment and health and safety at work. Furthermore, 'implied' ${ }^{10}$ EU competence in healthcare has been inferred from the reference in Article 2 EEC to raising 'the standard of living' and the imposition of a requirement on the Commission by Article 100A(3) EEC to base its proposals on a high level of health protection when taking harmonizing measures. ${ }^{11}$

The Council adopted measures to protect public health principally on the basis of Articles 100A(3) and 235 EEC, although some were subsequently linked to the 'explicit' competence of Article 152 EC $^{12}$ (now Article 168 TFEU). Further Council activity in the health field since the 1980s includes the notable examples of programmes against cancer and AIDS. In the 1990s, a range of specific programmes of cooperation were adopted, covering aspects as diverse as injury prevention and pollution-related diseases. More recently there has been a move away from sector- or condition-specific activity towards overall programmes focusing on improving health information and knowledge, creating a rapid and coordinated response to health threats and promoting health and preventing disease through addressing health determinants.

\section{Towards an 'explicit' competence}

The explicit competence of Article 168 TFEU (discussed below in the section on Legal Basis) has its origins in Article 129 EEC. This provision established a framework still discernible in Article 168 TFEU encompassing a requirement for Community involvement in ensuring a high level of human health protection, cooperation and coordination between Member States and the Commission and with third countries and international organisations, and stipulating specific procedures for adopting measures. ${ }^{13}$ The expansion of the Article 129 EEC framework by Article 152 EC $^{14}$ included various amendments, perhaps the most significant being an emphasis on specific public health concerns (as noted above), an introduction of a prohibition on the harmonisation of the laws and regulations of Member States, and a clause underscoring the responsibilities of Member States for the organisation and delivery of health services and medical care.

The development of what became Article 168 TFEU marks an expansion of EU competence in health law and policy. Certainly the development of this provision has been explained respectively in terms of perceptions that some problems relating to health policy (such as new diseases) were not amenable to resolution solely within national borders, preventing further 'creeping competence' of the EU into health matters, and representing a compromise between those Member States who did not want any EU mandate on health, and those who wanted to go further. ${ }^{15}$ Although the provision has been considered merely to formalize what was already happening in terms of EU

\footnotetext{
${ }^{10}$ Hervey and McHale draw a distinction between 'implied' and 'explicit' competence. See T.K. Hervey and J.V. McHale, 'Health Law and the European Union', (Cambridge University Press, 2004), pages 69-73. ${ }^{11}$ Discussed in M. McKee, T. Hervey, A.Gilmore, 'Public Health Policies', Chapter 5 in Mossialos et al. (2010) (n1).

${ }^{12}$ K. Lenaerts and P. Van Nuffel, 'European Union Law', Third Edition, Sweet and Maxwell, 2011. VIII Public Health, paragraph 11-053.

${ }^{13}$ See the respective provisions of Article 129 EEC, Article 152 EC and Article 168 TFEU.

${ }^{14}$ Hervey and McHale (2004) (n10) provide a comprehensive overview of the changes between Article 129 EEC and Article 152 EC.

${ }^{15}$ Hervey and McHale (2004) (n10). M.McKee, E.Mossialos, P.Belcher, 'The Influence of European Law on National Health Policy’ 6 Journal of European Social Policy (1996) 263.
} 
involvement in public health, this Treaty recognition has been described as setting health law on the road to becoming a recognized aspect of EU law. ${ }^{16}$

The 'public' dimension of 'health'

The expansion of Article 168 TFEU vis-à-vis its predecessors is informative with regard to expanding competence in substantive terms - that is, the range and definition of (public) health-related interests of the EU. Thus the provision has arguably expanded from general references to the 'prevention of diseases' and fighting 'the major health scourges' ${ }^{17}$ to ensuring 'a high level of human health protection' ${ }^{18}$ and 'improving public health'. ${ }^{19}$ This expansion is reflected in the incorporation of specific concerns. Article 168 TFEU continues the focus of Article $152 \mathrm{EC}$ on for example, high standards of quality and safety of organs and blood substances, ${ }^{20}$ and the veterinary field ${ }^{21}$ - apparently in response to crises surrounding HIV-infected blood and BSE/nvCJD the impact of which went beyond individual Member States. ${ }^{22}$ However, Article 168 TFEU builds on its predecessor by including direct references not only to adopting measures regarding 'the major cross-border health scourges' and tobacco and the abuse of alcohol in connection with the protection of public health, ${ }^{23}$ but also high standards of quality and safety for medicinal products and devices for medical use. ${ }^{24}$

In addition, the emphasis of Article 168 TFEU on public health ${ }^{25}$ is relevant to the question of whether health represents a special case.

- On the one hand, Article 168 TFEU itself replicates broadly the same structure as the provisions governing education and culture, which are characterized by comparable subsidiarity clauses and provisions enabling incentive measures. ${ }^{26}$ From this, and the increasing application of the internal market and competition rules to healthcare, it might be inferred that (public) health does not receive special treatment under EU law.

- On the other hand, the focus of a significant part of Article 168 TFEU on public health ${ }^{27}$ appears to offer an additional dimension to 'health', a wide concept which is defined in different ways in connection with different aspects of the Treaty.

\footnotetext{
${ }^{16}$ Hervey and McHale (2015) (n1), p.39.

${ }^{17}$ Article 129 EEC refers to 'the prevention of diseases, in particular the major health scourges, including drug dependence'. See also Article 152(1)EC and Article 168(5) TFEU.

${ }^{18}$ As part of the 'mainstreaming' provision of both Article 152(1) EC and Article 168(1) TFEU.

${ }^{19}$ See Article 152(1) EC: 'Community action [...] shall be directed towards improving public health, preventing human illness and diseases, and obviating sources of danger to human health. Such action shall cover the fight against the major health scourges, by promoting research into their causes, their transmission and their prevention, as well as health information and education'. Also

${ }^{20}$ See Article 152(4)(a) EC and Article 168(4)(a) TFEU.

${ }^{21}$ See Article 152(4)(b) EC and Article 168(4)(b) TFEU.

${ }^{22}$ Human immunodeficiency virus and Bovine Spongiform Encephalopathy/new variant Creuzfeld-Jacob

Disease, respectively.

${ }^{23}$ Article 168(5) TFEU.

${ }^{24}$ Article 168(4)(c) TFEU.

${ }^{25}$ Greer emphasizes public health in this way. See Greer et al. (2014) (n1).

${ }^{26}$ See Article 165 TFEU regarding education, and Article 167 TFEU regarding culture. Cf W. Sauter,

Public services in EU law (Cambridge University Press, Cambridge 2015).

${ }^{27}$ However, 'public health' is also implicit in the EU's environmental policy, a component of which is 'protection of human health' under Article 191 TFEU.
} 
At least two further facets of 'health' can be identified. Firstly, 'health' - typically combined with 'safety' - as one (nonetheless significant) aspect among several to be considered in the context of EU policies on, for example, employment ${ }^{28}$ and consumer protection. ${ }^{29}$ Secondly, the organization of the provision of health services and medical treatments within healthcare systems, as referenced in Article 168(7) TFEU and forms the focus of a growing body of literature regarding the internal market and competition rules and national healthcare systems. ${ }^{30}$ This organizational aspect of 'health' raises questions of expanding EU health law in the face of respective EU and Member State competence.

Although Article 168(7) TFEU appears to strengthen the role of Member States in defining health policy vis-à-vis its predecessors, ${ }^{31}$ its scope is appears to be circumscribed by new forms of economic governance and other aspects of EU law such as the Patients' Rights Directive, discussed below. This is discussed further in the sections below on subsidiarity and Governance. Indeed, although this organizational aspect may strengthen the view that healthcare is not a special case, it should be noted that references to healthcare have increased within guidance regarding the Services of General Economic Interest (SGEI) exception to the competition rules.

Article 168 TFEU is considered further in the section below on Legal Basis, but this brief historical overview arguably suggests that EU competence is expanding with regard to areas of concern, and that healthcare perhaps merits consideration as a special case. However the interaction between the respective EU and Member State competence and scope for harmonisation would benefit from further clarification. The scope for EU intervention with regard to harmonising measures is now considered in connection with two examples - tobacco and patients' rights.

\section{Healthcare (Article 168 TFEU) and harmonisation}

It will be recalled that Article 114 TFEU elaborates the EU's competence to adopt harmonizing measures for the approximation of Member State provisions which have as their object the establishing and functioning of the internal market. The prohibition on harmonization under Article 168(5) TFEU has therefore created interesting tensions between the two provisions, but both have been used as the basis for Directives in two very different aspects of healthcare - tobacco advertising and patients' rights.

\section{Example I: harmonisation and public health: tobacco}

The scope for harmonisation measures to be taken in the field of public health is demonstrated well by developments surrounding two Directives: the 2003 Tobacco

\footnotetext{
${ }^{28}$ Article 153(1)(a) TFEU stipulates that the EU shall support and complement the activities of Member States in improving the working environment to protect workers' health and safety.

${ }^{29}$ The Article 169 TFEU objective of promoting the interests of, and protecting consumers includes contributing to 'the health, safety and economic interests of consumers'.

${ }^{30}$ See, for example, L. Hancher and W. Sauter, 'EU Competition and Internal Market Law in the Health Care Sector' OUP 2012, T.K. Hervey, 'If Only It Were So Simple: Public Health Services and EU Law', Chapter 7 in eds. M.Cremona, 'Market Integration and Public Services in the European Union', OUP 2011. ${ }^{31}$ For example, Article 129(1) and (2) EEC merely restricted the European Community's role to encouraging cooperation between the Member States and supporting their action where necessary, and taking 'any useful initiative' to promote the coordination among Member States regarding their health policies and programmes. Article 152 EC generally reiterated this restricted role of Community action, but expressly stipulated that 'Community action in the field of public health shall fully respect the responsibilities of the Member States for the organization and delivery of health services and medical care', and added that incentive measures shall not affect national provisions on the donation or medical use of organs and blood.
} 
Advertising Directive (TAD) ${ }^{32}$ and the 2014 Tobacco Products Directive (TPD), ${ }^{33}$ both of which are based on Article 114 TFEU, the generic basis for internal market legislation. The TAD is considered here, and the TPD in connection with 'goods' below. At particular issue in connection with the TAD has been the tension between the use of Article 114 TFEU as a legal basis and the scope of Article 168(5) TFEU, which prohibits harmonisation measures. While it is perhaps too early to say whether this particular tension will be repeated in connection with the TPD, challenges of, and requests for preliminary rulings regarding, Article 114 TFEU as a legal basis are already emerging. ${ }^{34}$

Article 114 TFEU has proved to be a wide-ranging provision, forming the legal basis of most lifestyle-inspired legislation adopted by the EU to date, ${ }^{35}$ and criticism that it encourages 'competence creep' seems likely to continue since it replicates its predecessor (Article $95 \mathrm{EC}$ ) and in light of CJEU decisions which appear to soften the earlier stance that mere divergence in national laws was insufficient to warrant EU regulatory competence. ${ }^{36}$ It appears - partly on the basis of case law connected with the TAD - that a local 'safeguard clause' such as Article 168(5) TFEU would not directly limit Article 114 TFEU. ${ }^{37}$ Furthermore, even an express subsidiarity delineation (for example, of Article 168(7) TFEU) is thought unlikely to ever serve as a principal control device in respect of Article 114 TFEU. ${ }^{38}$

\section{The 2003 Tobacco Advertising Directive (TAD)}

In essence, the TAD prohibits forms of cigarette and tobacco advertising which take place away from the point of sale - television advertising having been prohibited separately prior to this. ${ }^{39}$ The present $\mathrm{TAD}^{40}$ supersedes a previous version ${ }^{41}$ which was annulled by the Tobacco Advertising I case. ${ }^{42}$ This case involved a challenge by Germany that the

\footnotetext{
${ }^{32}$ European Parliament and Council Directive 2003/33 on the approximation of laws relating to advertising and sponsorship of tobacco products[2003] OJ L152/16.

${ }^{33}$ Directive 2014/40/EU of the European Parliament and of the council of 3 April 2014 on the approximation of the laws, regulations and administrative provisions of the Member States concerning the manufacture, presentation and sale of tobacco and related products and repealing Directive 2001/37/EC.

${ }^{34}$ Case C-358/14 Action brought on 22 July 2014 - Republic of Poland v European Parliament and Council of the European Union. Case C-477/14 Reference for a preliminary ruling from High Court of Justice Queen's Bench Division (Administrative Court) (England and Wales) (United Kingdom) made on 27 October 2014 - Pillbox 38 (UK) Limited, trading as 'Totally Wicked' v Secretary of State for Health. Case C-547/14 Reference for a preliminary ruling from the High Court of Justice, Queen's Bench Division (Administrative Court) (England and Wales) (United Kingdom) made on 1 December 2014 - Philip Morris Brands SARL, Philip Morris Limited, British American Tobacco UK Limited against Secretary of State for Health.

${ }^{35}$ A. Alemanno and A. Garde, 'The emergence of an EU lifestyle policy: the case of alcohol, tobacco and unhealthy diets', Common Market Law Review 50: 1745-1786, 2013.

${ }^{36}$ P. Craig, 'The Lisbon Treaty - Law, Politics and Treaty Reform', OUP 2013. P.189.

${ }^{37}$ R. Schütze, 'Limits to the Union's 'Internal Market' Competence(s): Constitutional Comparisons', Chapter 10 in ed. L. Azoulai, 'The Question of Competence in the European Union', OUP 2014. P.231. ${ }^{38}$ Craig (n64).

${ }^{39}$ By the Television Without Borders Directive - Council Directive 89/552/EEC on the coordination of certain provisions laid down by Law, regulation or Administrative Action in Member States concerning the pursuit of television broadcasting activities [1989] OJ L298/33.

40 Directive 2003/33/EC of the European Parliament and of the Council of 26 May 2003 on the approximation of the laws, regulations and administrative provisions of the Member States relating to the advertising and sponsorship of tobacco products.

${ }^{41}$ Directive $98 / 43$ on the approximation of the laws, regulations and administrative provisions of the Member States relating to the advertising and sponsorship of tobacco products [1998] OJ L213/9.

${ }^{42}$ Case C-376/98 Judgment of the Court of 5 October 2000. Federal Republic of Germany v European Parliament and Council of the European Union. Directive 98/43/EC - Advertising and Sponsorship of
} 
Treaty provisions used as a legal basis for the directive, including Article 114 TFEU, were inappropriate. Of particular note are three clarifications by the CJEU. Firstly, that the harmonisation prohibition of Article 168(5) TFEU does not mean that harmonising measures adopted on the basis of other provisions of the Treaty cannot have any impact on the protection of human health. ${ }^{43}$ Secondly, that other Treaty articles may not be used as a legal basis in order to circumvent the express harmonisation exclusion laid down in Article 168(5) TFEU. ${ }^{44}$ Thirdly, the CJEU stated that, provided the conditions to recourse to Article 114 TFEU (and the other Articles forming the basis for the Directive) are fulfilled, the Community legislature cannot be prevented from relying on that legal basis on the ground that public health protection is a decisive factor in the choices to be made. The requirements of Article 168(1)(3) TFEU (that health requirements are to form a constituent part of the Community's other policies) and Article 114(3) TFEU (that in the process of harmonisation a high level of human health protection is to be ensured) lend support to this view. ${ }^{45}$ Ultimately the CJEU saw fit not merely to sever specific provisions, but to annul the directive in full as the provisions concerned were so interconnected with the directive as a whole. However, the Council and the European Parliament subsequently readopted the directive with the offending parts removed. ${ }^{46}$

Germany brought a further challenge in the Tobacco Advertising II case, ${ }^{47}$ again regarding the legal basis of Articles 114 and 168(5) TFEU in respect of the prohibition in Articles 3 and 4 of the TAD on the advertising and sponsorship in respect of tobacco products in printed media, in information society services and in radio broadcasts. The CJEU took this opportunity to clarify further the relationship between the two Treaty provisions by reference to the Tobacco Advertising I judgment: namely by reiterating that the harmonisation prohibition of Article 168(5) TFEU does not mean that harmonising measures adopted on the basis of other Treaty provisions cannot have any impact on the protection of human health. ${ }^{48}$ This led to the conclusion that this related plea was unfounded so was therefore dismissed and the validity of Articles 3 and 4 of the TAD was upheld.

\section{Example II: harmonisation and patients' rights}

A recent example where the scope of EU law with regard to healthcare was extended significantly is that of patients' rights to medical treatment in other (host) Member States, and to reimbursement of such treatment in the home Member State. Initially these rights were established in case law by the European Court of Justice in prejudicial rulings provided in response to questions raised by national courts on the interpretation of the

tobacco products - Legal basis - Article 100a of the EC Treaty (now, after amendment, Article 95 EC). European Court Reports 2000 I-08419. Summary, para 3.

${ }^{43}$ Case C-376/98, para 78.

${ }^{44}$ Case C-376/98, para 79.

${ }^{45}$ Case C-376/98, para 88.

${ }^{46}$ For a discussion of this, see C. Barnard, 'The Substantive Law of the EU', Fourth Edition, OUP 2013 pp. 635-8.

${ }^{47}$ Case C-380/03 Judgment of the Court (Grand Chamber) of 12 December 2006. Federal Republic of Germany v European Parliament and Council of the European Union. Action for annulment Approximation of laws - Directive 2003/33/EC - Advertising and sponsorship in respect of tobacco products - Annulment of Articles 3 and 4 - Choice of legal basis - Articles 95 EC and 152 EC - Principle of proportionality. European Court Reports 2006 page I-11573.

${ }^{48}$ Case C-380/03, para 95. 
relevant EU rules. ${ }^{49}$ These primarily concerned the freedom of services, which included the freedom to provide as well as to receive services, in cases where either (i) the provider or (ii) the recipient or the (iii) service itself crosses a national border within the EU.

This case law, called the patients' rights or patient mobility case law, started with regard to restitution systems with Kohll and Decker (1998), was extended to benefits in kind systems in Smits Peerbooms (2001) and Müller-Fauré (2003) and finally to NHS systems in Watts (2006). In each case the home Member State was required to reimburse the costs of cross-border treatment. It gave rise to criticism that the Court was eroding national welfare states and rewarded queue jumping by well-heeled patients who could afford to travel abroad while siphoning funds from cash-strapped national systems.

However subsequent research by the European Commission has shown that only about $1 \%$ of healthcare has a cross-border dimension and there are strong reasons why most patients prefer to be treated close to home. ${ }^{50}$ Also the case law required waiting lists (which were then prevalent in most of the EU) to be based on the health status of the individual, including the degree of pain or discomfort and its relevance to their employment. This humanized the use of waiting lists even in cases without a cross-border dimension. Once all Member States' systems were covered by the case law the national governments had a strong incentive to proceed to harmonization: this would ensure the rules formulated by the Court were made coherent, while at the same time giving the Member States a modicum of control.

The relevant legislation consists of two Directives. Firstly this concerns the 2006 Services Directive, which initially contained a single article on healthcare but following vocal resistance against its original draft was eventually recast in such a way as to explicitly exclude healthcare altogether. ${ }^{51}$ Second, and consequently, this concerns the Patients' rights Directive, a codification of the case law which filled the resultant gap in a much more extensive way than had been the starting point in the Services Directive. ${ }^{52} \mathrm{We}$ therefore note that an attempt to limit the scope of EU intervention in healthcare legislation was transformed into the reverse: a much more significant piece of legislation that also involved a further extension of the scope of EU law in healthcare. The legal basis of the Patients' rights Directive was a combination of Article 114 TFEU (the

\footnotetext{
${ }^{49}$ Case C-158/96 Raymond Kohll v Union des caisses de maladie [1998] ECR I-1931; Case 120/95 Nicolas Decker v Caisse de maladie des employés privés [1998] ECR I-1831; Case C-157/99 Geraets-Smits v Stichting Ziekenfonds VGZ and H.T.M. Peerbooms v Stichting CZ Groep Zorgverzekeringen [2001] ECR I-5473; Case C-385/99 Müller-Fauré v Onderlinge Waarborgmaatschappij OZ Zorgverzekeringen UA and E.E.M. van Riet v Onderlinge Waarborgmaatschappij ZAO Zorgverzekeringen [2003] ECR I-4509; case C-372/04 The Queen, on the application of Yvonne Watts $v$ Bedford Primary Care Trust and Secretary of State for Health (Watts) [2006] ECR I-4325.

${ }^{50}$ Commission staff working document of 2 July 2008, accompanying document to the proposed patients' rights Directive: Impact Assessment, SEC(2008) 2163. T. Clemens, K. Michelsen and H. Brand, 'Supporting health systems in Europe: added value of EU actions?' Health Economics, Policy and Law 9 (2014) 49-69.

${ }^{51}$ Directive 2006/123/EC of the European Parliament and of the Council of 12 December 2006 on services in the internal market, OJ 2006, L376/36. C. Barnard, 'Unravelling the services Directive' (2008) 45 Common Market Law Review 45 (2008) 323-394.

52 Directive 2011/24/EU of the European Parliament and of the Council of 9 March 2011 on the application of patients' rights in cross-border healthcare, OJ 2011, L88/45. W. Sauter, 'Harmonization in health care: the EU patients' rights Directive', in B. Cantillon, H. Verschuren en P. Ploscar (red), Social inclusion and social protection in the EU: Interaction between law and policy (Intersentia, Antwerpen 2012), 105-129
} 
generic basis for internal market legislation) and Article 168 TFEU (the healthcare provision). ${ }^{53}$

The Patients' rights Directive considerably extended the scope of the EU's involvement in healthcare. Although in line with Article 168 TFEU the organization and delivery of health services within national health systems were not affected the Member States were required to reimburse cross-border care subject only to restrictively defined exceptions. They were also to provide information about quality and costs, as well as providing for professional liability and damages. In addition the Directive provided provisions covering enhanced cooperation on rare diseases and e-health. Hence individual rights based on free movement here led to case law that triggered harmonization legislation extending new rights generally. This leads us to consider in more detail the legal basis and scope for such efforts.

\section{Legal Basis and Scope}

EU health law has been considered to cut across the taxonomy accepted by EU lawyers as establishing the categories of EU law, thus we need to look at the health implications of many areas of EU law ${ }^{54}$ in order to understand the legal basis and scope for EU intervention. These comprise the fields in which the EU institutions may act, the forms such acts may take and the procedure by which they may be adopted. ${ }^{55}$ While it might be considered that EU competence in the area of health law and policy has been expanded by Article 168 TFEU, examining other aspects of the Treaty reveal the effect of more general trends, in relation to how health is perceived (and thus whether it constitutes a special case). Thus at least three distinctions might be drawn. Firstly between, for example, implied and explicit competence, ${ }^{56}$ where the TFEU may either grant an explicit power or require the achievement of an objective. Secondly, between Member State and EU competence, with increasing instances of 'shared' competences. Thirdly, between powers with a direct health objective, and powers indirectly related to health, ${ }^{57}$ such as the internal market.

With regard to 'direct' health-related powers, it is useful to note that these may overlap with, and even be reflected in, Article 168 TFEU, both in terms of focus and whether the competence belongs to the EU and/or Member States. For example, Article 4(2)(k) TFEU elaborates 'common safety concerns in public health matters, for the aspects defined in this Treaty' as a competence which the EU shares with Member States. This is in contrast to Article 6(a) TFEU, which stipulates 'the protection and improvement of human health' among the fields where the EU's competence is limited to supporting, coordinating or supplementing the actions of the Member States. Furthermore, Article 9 TFEU includes 'protection of human health' alongside, inter alia, a high level of education, as among the requirements the EU must consider in defining and limiting its policies and activities.

\section{Article 168 TFEU}

This section considers the general legal basis of Article 168 TFEU - as broadly setting out explicit and largely shared competence for the EU. It then considers in overview the

\footnotetext{
${ }^{53}$ V. Hatzopoulos and T. Hervey, 'Coming into line: the EU's Court softens on cross-border healthcare', Health Economics, Policy and Law 8 (2013) 1-5.

${ }^{54}$ T.K. Hervey, 'EU Health Law', Chapter 21 in eds. C. Barnard and S. Peers, 'EU Law', OUP 2014.

${ }^{55}$ Hervey and McHale (2004) (n10), p.71.

${ }^{56}$ Ibid, p. 70.

${ }^{57}$ Greer et al. (2014) (n1) pages 19-25.
} 
legal basis and scope of Article 168(1)-(6) TFEU before examining the subsidiarity element of Article 168(7) TFEU.

As noted in the 'History' section above, Article 168 TFEU has been deemed an 'explicit' competence. Its legal basis builds on that of its predecessor Article $152 \mathrm{EC}$ by introducing competence to adopt two further types of measure. ${ }^{58}$ Firstly, legislative measures setting high standards of quality and safety for medicinal products and devices for medical use. ${ }^{59}$ Secondly, incentive measures concerning monitoring, early warning of and combating serious cross-border threats to health, and measures which have as their direct objective the protection of public health regarding tobacco and the abuse of alcohol, excluding any harmonisation of the laws and regulations of the Member States. ${ }^{60}$ In addition, Article 168 TFEU reinforces the subsidiarity principle with regard to healthcare systems ${ }^{61}$ by stipulating that the responsibilities of Member States shall include the management of health services and medical care and the allocation of the resources assigned to them.

\section{Overview of the legal basis and scope of Article 168(1)-(6) TFEU}

As noted with regard to the development of the history of Article 168 TFEU, the provision marks a specific legal basis and scope in the field of public health, following earlier provisions which are more general in their scope. This focus has been considered a deliberate attempt by the drafters of the treaties to orient EU action towards populationlevel measures and away from action on health services, something which is reflected in the objectives of the Article being focused toward public health activities and health determinants (tobacco and alcohol being specifically mentioned). ${ }^{62}$

\section{Mainstreaming}

Article 168(1) TFEU, with its opening requirement that 'A high level of human health protection shall be ensured in the definition and implementation of all Union policies and activities', is considered a 'mainstreaming' provision, ${ }^{63}$ or 'integration clause' ${ }^{64}$ While this provision has not been considered to provide a basis for additional measures ${ }^{65}$ attempts to incorporate healthcare-related considerations into other policy areas has been given further impetus at both Member State and EU level by initiatives such as Health Impact Assessments (HIAs) and Health in all Policies (HiAP). ${ }^{6667}$ Indeed, although Article 168(1) TFEU has been considered to impose a requirement to follow the HiAP approach, ${ }^{68}$ this appears to require further work to implement. ${ }^{69}$

\footnotetext{
${ }^{58}$ Discussed in J-C Piris, 'The Lisbon Treaty - A Legal and Political Analysis' CUP 2010, pp.320-1.

${ }^{59}$ Article 168(4)(c) TFEU.

${ }^{60}$ Article 168(5) TFEU.

${ }^{61}$ Article 168(7) TFEU.

${ }^{62}$ Greer et al. (2014) (n1).

${ }^{63}$ Hervey and McHale (2004) (n23).

${ }^{64}$ Greer et al. (2014) (n1).

${ }^{65}$ Ibid.

${ }^{66}$ One distinction between the two initiatives is that HiAP is not necessarily bound or limited to a single measure, but can extend and be applied in the context of political decision-making and accountability. See M. Koivusalo, 'The state of Health in All Policies (HiAP) in the European Union: potential and pitfalls', J Epidemiol Community Health 2010; 64:500-503.

${ }^{67}$ For an overview of the HiAP approach and its implementation within the EU and Member States, see E Ollila, T Ståhl, M Wismar, E Lahtinen, T Melkas, K Leppo, 'Health in All Policies in the European Union and its Member States' - available at http://ec.europa.eu/health/ph_projects/2005/action1/docs/2005_1_18_frep_a4_en.pdf

${ }^{68} \mathrm{See}$ http://ec.europa.eu/health/health_policies/policy/index_en.htm and Koivusalo (n66).

${ }^{69}$ See E Ollila, 'Health in All Policies: From rhetoric to action', Scandinavian Journal of Public Health, 2011; 39 (Suppl 6): 11-18.
} 


\section{Cooperation}

Article 168(2) TFEU encourages cooperation between Member States with reference in particular to improving the complementarity of their health services in cross-border areas. The provision further empowers the Commission to take any useful initiative to promote such coordination, such as initiatives aiming at the establishment of guidelines and indicators, the organisation of exchange of best practice, and the preparation of the necessary elements for periodic monitoring and evaluation. Furthermore, the European Parliament shall be kept fully informed. This framework has been linked to the 'open method of coordination' (OMC) previously implemented in the area of employment. ${ }^{70}$ The use of the OMC - a form of intergovernmental policy-making that does not result in binding EU legislative measures ${ }^{71}$ - in the healthcare context is considered further in the Governance section below. It has been noted that while Article 168(2) TFEU does not confer any direct powers on the EU, this method nevertheless exposes Member States to peer review, which may eventually persuade them to adapt their policies. $^{72}$

Article 168(3) TFEU sets out a requirement for the EU and Member States to foster cooperation with third countries and the competent international organisations in the sphere of public health. This consolidates and reconfirms EU external competence rules, ${ }^{73}$ implicit use of which was made in the EU signing the World Health Organisation (WHO) Framework Convention on Tobacco Control in 2003. What might be termed 'external EU health law' has found expression in the EU's 'common commercial policy' and development cooperation policy, as well as international agreements in response to specific public health scares. ${ }^{74}$

\section{Public health}

Article 168(4) TFEU sets out the procedure for EU institutions to take action in connection with public health, specifically adopting measures to meet common safety concerns. It delimits a potentially wide-ranging competence to specific areas, namely, high standards of quality and safety regarding organs and substances of human origin, blood and blood derivatives and also regarding medicinal products and devices for medical use, and measures in the veterinary and phytosanitary fields which have as their direct objective the protection of public health ${ }^{75}$ While the inclusion of some of these specific examples can be attributed to public health crises such as BSE/nvCJD (as regards the veterinary field) and scandals relating to the distribution and transfusion of HIVinfected blood and blood products, it has also been considered that an embryonic 'market' in human blood, organs and other substances is emerging in the EU and that using the ordinary internal market provisions to regulate this 'market' is ethically and politically sensitive in many Member States. ${ }^{76}$ Article 168(4)(c) TFEU adds a further provision regarding medicinal products and devices for medical use, which might be seen in a similar light, namely, as markets in need of regulation beyond the scope of the internal market provisions which govern these.

\footnotetext{
${ }^{70}$ Lenaerts and Van Nuffel (n12).

${ }^{71}$ http://eur-lex.europa.eu/summary/glossary/open_method_coordination.html .

72 Lenaerts and Van Nuffel (n12).

${ }^{73}$ Hervey (2014) (n54).

${ }^{74}$ For a comprehensive discussion, see Hervey (2014) (n54).

${ }^{75}$ Article 168(4)(a)-(c) TFEU.

${ }^{76}$ For a discussion of this, see Hervey and McHale (2004) (n10), p.80.
} 
Article 168(5) TFEU describes the procedure by which the European Parliament and the Council may adopt incentive measures, and the wide scope in terms of substantive concerns where these institutions may intervene - namely, protecting and improving human health with a particular emphasis on combatting the major cross-border health scourges, and measures which directly aim at protecting public health regarding tobacco and the abuse of alcohol. This potentially wide-ranging scope for intervention is, however, circumscribed by an exclusion on harmonising the laws and regulations of Member States. A potential tension between 'incentive measures' which explicitly preclude harmonisation provisions, and 'measures', which implicitly include harmonising regulations, directives or other acts has been noted, ${ }^{77}$ and the actual tension between Article 168(5) TFEU and Article 114 TFEU as regards scope for harmonisation has been considered in connection with the Tobacco Advertising cases and as the dual legal basis for the Patients' Rights Directive above.

Article 168(6) TFEU empowers the Council to adopt recommendations for the purposes set out in this Article on a proposal from the Commission.

\section{Article 168(7) TFEU - healthcare and subsidiarity}

In contrast to the foregoing subsections (Article 168(1)-(6)), Article 168(7) TFEU might be considered to offer a delineating feature of the scope of EU-level competence in healthcare by its allusion to subsidiarity in requiring EU action to respect the responsibilities of Member States for the definition of their health policy and for the organisation and delivery of health services and medical care.

Article 168(7) TFEU builds on its predecessors by providing that 'Union action shall respect the responsibilities of the Member States for the definition of their health policy and for the organization and delivery of health services and medical care.' The 'responsibilities of the Member States' are elaborated as including 'the management of health services and medical care and the allocation of the resources assigned to them'.

It would therefore appear that 'subsidiarity' in the context of Article 168(7) TFEU is concerned with the 'systemic' focus of healthcare in light of the references to 'organization and delivery of health services and medical care'. This 'systemic' focus can be distinguished from an 'individual' focus, which broadly encompasses the implications of the internal market rules for patients, healthcare professionals and healthcare products, as well as human rights aspects in respect of access to healthcare. ${ }^{78}$ The 'systemic' focus might therefore be considered to be concerned primarily with the impact of the EU competition rules on the associated issues of solidarity and equality. ${ }^{79}$ This raises interesting questions about the expanding scope of EU intervention vis-à-vis different types of healthcare system as much as concerns about EU-Member State dynamics.

As noted above, healthcare systems in EU Member States have typically been described as falling within the broad categories of the Bismarck social insurance model or the

\footnotetext{
${ }^{77}$ In connection with Article 152(4) EC - see Hervey and McHale (2004) (n10), p.79.

${ }^{78}$ In their extremely comprehensive review of EU health law, Hervey and McHale (2015) (n1) devote separate parts to 'individual focus' and 'systemic focus'.

${ }^{79}$ Hervey and McHale discuss health insurance, health institutions and professions and the pharmaceuticals, medical devices and medical equipment industries in light of competition, solidarity and equality. See Hervey and McHale (2015) (n1), Chapters 9-11. They also include 'risk' as part of the 'systemic' focus in connection with clinical trials, health system products (pharmaceuticals, human blood, tissue and cells, organs), medical devices, tobacco, food and alcohol. See Hervey and McHale (2015) (n1), Chapters 12-15.
} 
Beveridge taxation-funded model. However, other conceptions are possible: for example, it has recently been suggested that Member State healthcare systems effectively make up the centre ground of a 'simple continuum' which spans planned economies, constrained competition/modified liberalism and neoliberal economies. ${ }^{80}$ It might be inferred, therefore, that Article 168(7) TFEU enshrines a 'freedom' for Member States to determine where their healthcare systems belong on this continuum, or within the Bismarck/Beveridge typology. It arguably follows that it is the choice of a given Member State to introduce reforms which determines, for instance, application of the competition rules, as opposed to this being mandated at EU level. In other words, expanding scope for EU intervention in healthcare with regard to the application of the competition rules is driven, perhaps counterintuitively, by activity at the Member State level.

However, there are two ways in which Article 168(7) TFEU appears to represent an obstacle to be overcome in terms of expanding EU-level competence in healthcare.

- Firstly, the aforementioned 'freedom' for Member States to adopt a specific healthcare model/system leads to a lack of legal certainty regarding how EU competition rules should be applied. Thus, although both the Netherlands and England have recently instituted reforms thought to trigger application of the competition rules, how these are being applied varies considerably, in part due to there being greater scope for competition in a Bismarck rather than a Beveridge system. ${ }^{81}$ The resulting scope for potential legal uncertainty has been described in terms of emerging 'Euro-national competition rules', ${ }^{82}$ as distinct from a process of 'spontaneous harmonization' as Member States experiment with varying degrees of private provision and competition in their healthcare systems.

- Secondly, although Article 168(7) TFEU acts as a restraining force on further expansion of EU-level competence in healthcare, this may have the effect that the EU institutions explore alternative avenues to increase their competence in connection with healthcare, or that increased competence is the effect, if not a stated desire. This growing encroachment of EU intervention into healthcare matters which might be considered reserved to national level by Article 168(7) TFEU may be explained in terms of negative integration, driven by the EU institutions without democratic legitimacy or an obvious justification. ${ }^{83}$

The idea of alternative avenues relates to the conceptions of social and political spillover. ${ }^{84}$ An example of social spillover might be older UK citizens retiring to Spain that is, a group taking advantage of one EU policy (freedom of movement) having the effect of forcing Member States to integrate other policy areas (coordination of social security and healthcare). ${ }^{85}$ Political spillover describes the situation in which

\footnotetext{
${ }^{80}$ For this conception, Hervey and McHale draw on Hall and Soskice's 'Varieties of Capitalism'. See Hervey and McHale (2015) (n1) p.222.

${ }^{81}$ Hancher, Sauter (2012) (n30), p.232-3.

82 J. Van de Gronden, 'The Treaty Provisions on Competition and Health Care', Chapter 11 in eds. J. Van de Gronden. E.Szyszczak, U. Neergaard, M.Krajewski, Health Care and EU Law (TMC Asser Press, 2011) and J. Van de Gronden and E. Szyszczak, 'Introducing competition principles into health care through EU law and policy: a case study of The Netherlands'. Medical Law Review, (2014) 22 (2). pp. 238-254.

${ }^{83}$ Scott L. Greer, 'Health policy in the European Union', Ch. 2 in Scott L. Greer, 'The Politics of European Union Health Policies', Open University Press 2009. P.11.

${ }^{84}$ Ibid.

${ }^{85}$ Ibid, p. 10.
} 
supranational policy arenas emerge out of integration in a policy area starting with interest groups and an EU institution. ${ }^{86}$ This is perhaps more relevant to the 'risk' aspect of the 'systemic focus', ${ }^{87}$ but it may be the case that ostensibly Member State-driven initiatives such as the OMC (discussed below) have an effect here too.

These spillovers clearly influence the scope of EU-level intervention in healthcare but arguably do not conflict directly with Article 168(7) TFEU. In contrast, it may become possible to talk of a new category ${ }^{88}$ - perhaps termed 'economic spillover' - to describe the effect on healthcare systems of the European Semester and other economic agreements. This is discussed further below in the section on governance. However, it is suggested here that the binding recommendations of such agreements offer scope for conflict with the 'systemic focus' of Article 168(7) TFEU, thus potentially paving the way for 'Europeanization' of healthcare ${ }^{89}$ despite the subsidiarity provision.

In this view, the next question is: how and when do internal market and competition law affect health? This is now considered further.

\section{Internal market}

The internal market is one of the core pillars of the EU, and one of the oldest. It consists of an internal space that is characterized by the free movement of the factors of production, goods, services, persons (including establishment), and capital (including payments). In effect this means that the internal market should function as if it had no internal borders. In addition the overriding objective of the competition rules (antitrust, as well as merger and State aid control) is to ensure the internal market is characterized by free competition. In this manner barriers by governments (free movement) and by undertakings (competition) are to be levelled.

As we shall see the market levelling nature of the internal market indirectly impacts healthcare. However the internal market is not just about levelling barriers. Because some of the public restrictions can be justified objectively - such as by concerns about health and safety - EU law also provides for harmonisation of such rules. This means a set of common rules is drafted and then implemented in all Member States. The degree of harmonization can differ from full of maximum harmonization to partial or minimum harmonization. In the latter case only basic standards are set and Member States remain free to adopt higher standards.

Both of the two case studies set out above, both the Patients' rights Directive and the Tobacco Directives are examples of harmonization that concern healthcare. They show the interaction with the case law: the Patients' rights Directive formed a codification of such case law, whereas the cases on the Tobacco Directive show how the Court guards the application of the appropriate legal basis for healthcare legislation. Below we will look in more detail at the various sectors within the internal market legislation.

\footnotetext{
${ }^{86}$ Ibid, p.11.

${ }^{87}$ Hervey and McHale (2015) (n1).

${ }^{88}$ Influenced not only by Greer (2009) (n83), but also Greer's 'three faces' of EU health policy in S L Greer, 'The three faces of European Union health policy: Policy, markets and austerity', Policy and Society 33 (2014) 13-24.

${ }^{89}$ Sindbjerg Martinsen and Vrangbæk have previously suggested that healthcare constituted a 'less likely' case for Europeanization in view of Article 152 EC, particularly in connection with the Danish healthcare system. See D. Sindbjerg Martinsen and K. Vrangbæk, 'The Europeanization of Health Care Governance: Implementing the Market Imperatives of Europe', Public Administration (2008), Vol.86, No.1, 169-184.
} 


\section{Free movement of services}

The freedom to provide and/or receive services is important in the healthcare context because this covers healthcare provision across borders. However because above we have already dealt with services and patient mobility in detail by way of a case study we will not go further into this topic here.

\section{Free movement of persons: social security coordination}

The earliest provisions of secondary EU law on healthcare are the rules for workers in the context of social security coordination. These are set out in fully binding form (requiring in principle no further implementation measures) in EU Regulations. Their scope has gradually been extended to cover all EU citizens and their dependents. Supplementary legislation has extended the scope to third country nationals who are legal residents. ${ }^{90}$ This legislation also includes a system for reimbursement of cross-border treatment that is based on the level of reimbursement in the host country and not the home country as in the Patients' Rights Directive.

In fact where both routes are available the social services coordination legislation has priority - unless the patient specifically invokes the Directive. In theory the provisions of the Patients' rights Directive could have been incorporated in the social security coordination regime, obviating the need for a separate Directive. In practice the social security regime, which is much broader than just healthcare, ${ }^{91}$ had recently been renewed following lengthy negotiations and the Member States preferred having a specific healthcare Directive on the side with some overlap to reopening the negotiations on social security.

\section{Freedom of establishment}

Regarding the freedom of establishment an increasing number of cases has come before the EU courts without a comparable development to that concerning services taking place. It may be that regulation of supply is more intractable than that of demand, where the rights of individual EU consumers (or citizens) play a role. ${ }^{92}$

\section{Medical qualifications}

A relatively early form of EU legislation on healthcare are the provisions with regard to the mutual recognition of medical qualifications. It emerged as part of the 1992 programme of completing the internal market by that year. In reality of course the internal market is still not complete, nor is it likely to be completed soon, although progress has been made. The use of the instrument of Directives (which must normally be

\footnotetext{
90 Regulation (EC) No 883/2004; Council Regulation (EEC) No 1408/71 of 14 June 1971 on the application of social security schemes to employed persons, to self- employed persons and to members of their families moving within the Community; which are applicable by virtue of Regulation (EU) No 1231/2010 of the European Parliament and of the Council of 24 November 2010 extending Regulation (EC) No 883/2004 and Regulation (EC) No 987/2009 to nationals of third countries who are not already covered by these Regulations solely on the ground of their nationality; Council Regulation (EC) No 859/2003 of 14 May 2003 extending the provisions of Regulation (EEC) No 1408/71 and Regulation (EEC) No 574/72 to nationals of third countries who are not already covered by those provisions solely on the ground of their nationality.

91 That is, apart from sickness; maternity and paternity; old-age pensions; preretirement and invalidity pensions; survivors' benefits and death grants; unemployment; family benefits; accidents at work and occupational illness.

${ }^{92}$ L. Hancher and W. Sauter, 'One step beyond? From Sodemare to Docmorris: The EU's freedom of establishment case law concerning healthcare', 47 Common Market Law Review (2010) 117-146.
} 
implemented in national law in order to take full effect) and of the mechanism of mutual recognition is typical for the 'new approach' to integration by EU law. As such it follows the Cassis de Dijon case law of the Court and is based on the assumption that identical public interest guarantees are not necessary for free movement across borders because they are assumed to be equivalent between the Member States. ${ }^{93}$

The legislation regarding the freedom of establishment is necessary to enable free movement of healthcare workers. In line with mutual recognition the essential feature is that once a healthcare worker is qualified to practice in a single EU Member State, he or she is automatically qualified to work elsewhere in the EU as well, provided minimal requirements (notably the necessary language skills) are met. Prior sectoral Directives have been consolidated in the 2005 general mutual recognition of professional qualifications Directive covering (among a range of other non-medical professors) doctors, general nurses, midwives, (general) dentists and pharmacists. ${ }^{94}$ This is therefore part of a horizontal framework for all types of professions.

\section{Pharmacies}

This sector has seen a relatively large number of cases where the rules governing the spatial distribution of pharmacies and/or licences were contested. ${ }^{95}$ It is worth noting that restrictions of competition by means of private regulation by an industry body have also been addressed under the antitrust rules in the ONP Case. ${ }^{96}$

\section{Free movement of goods}

Regarding healthcare and the internal market we are initially inclined to think primarily of the provision of services. However healthcare goods are also highly significant in terms of turnover, trade and healthcare impact, in particular pharmaceuticals and medical devices, without which healthcare services could not be delivered.$^{97}$ For both pharmaceuticals and medical devices Article 168(4) TFEU contains an exception to the primacy of the Member States in healthcare, whereby the EU can pursue a high level of quality and safety by means of legislation (according to the ordinary legislative procedure). Balancing healthcare needs with the functioning of the internal market and promoting innovation is the main objective here.

\section{Pharmaceuticals}

For pharmaceuticals three types of rules are important: (i) the patent rules (ii) rules on admission to market (iii) price transparency rules. The EU patent rules are general in nature (for all sectors) and do not include specific provisions for pharmaceuticals although this is one of the leading sectors in patent applications. Marketing authorisation

\footnotetext{
${ }^{93}$ Case 120/78 Rewe-Zentral AG v Bundesmonopolverwaltung für Branntwein [1979] ECR 649.

${ }^{94}$ Directive 2005/36/EC of the European Parliament and of the Council of 7 September 2005 on the recognition of professional qualifications, OJ 2005, L255/22.

${ }^{95}$ Joined cases C-171/07 and C-172/07 Apothekerkammer des Saarlandes and Others (C-171/07) and Helga Neumann-Seiwert (C-172/07) v Saarland and Ministerium für Justiz, Gesundheit und Soziales [2009] ECR I-4171; Case C-531/06 Commission v Italy [2009] ECR I-4103; Joined cases C-570/07 and C-571/07 José Manuel Blanco Pérez and María del Pilar Chao Gómez v Consejería de Salud y Servicios Sanitarios (C570/07) and Principado de Asturias (C-571/07) [2010] ECR I-4629; Case C-84/11 Marja-Liisa Susisalo, Olli Tuomaala and Merja Ritala, Judgment of 21 June 2012.

${ }^{96}$ Case T-90/11 Ordre national des pharmaciens (ONP) et al. v Commission, Judgment of 10 December 2014.

${ }^{97}$ C. Altenstetter and G. Permanand, 'EU regulation of medical devices and pharmaceuticals in comparative perspective', Review of Policy Research 24 (2007) 385-405.
} 
for pharmaceuticals has been harmonized in general terms at EU level. ${ }^{98}$ In addition there are rules for special types of medication (orphan drugs, children's medication and advanced therapy). ${ }^{99}$ The most direct intervention is that on price transparency, which includes time limits on decisions in this area and the requirement that they must be justified objectively, non-discriminatory and (evidently) transparent. ${ }^{100}$ A new Directive on this topic has been proposed. ${ }^{101}$

\section{$\underline{\text { Medical devices }}$}

Like pharmaceuticals, medical devices are goods, and in some cases they closely resemble pharmaceuticals. Distinguishing medical devices from pharmaceuticals is in fact one of the purposes of EU legislation, which is necessary because different legal frameworks apply to the two categories. The medical devices regime consists of three directives: the 1993 general Directive on medical devices ${ }^{102}$ and two specific Directives, the 1990 Directive on implantable devices, ${ }^{103}$ and the 1998 Directive on in vitro diagnostic devices. ${ }^{104}$ At present the three Medical Devices Directives are being recast and consolidated in the form of two Regulations (which are binding as such and do not need to be transposed into national law in order to have effect) on Medical Devices.

\section{$\underline{\text { Tobacco }}$}

Although in some ways explicitly classified as a public health concern under Article 168(5) TFEU, tobacco is of course also a good and accordingly subject to the free movement rules. This appears to suggest that it occupies an interesting place between

\footnotetext{
${ }^{98}$ Directive 2001/83/EC of the European Parliament and of the Council of 6 November 2001 on the Community code relating to medicinal products for human use, OJ 2001, L311/67; Regulation (EC) No 726/2004 of the European Parliament and of the Council of 31 March 2004, OJ 2004, L136/1. laying down Community procedures for the authorisation and supervision of medicinal products for human and veterinary use and establishing a European Medicines Agency.

${ }^{99}$ Regulation (EC) No 141/2000 of the European Parliament and of the Council of 16 December 1999 on orphan medicinal products, OJ 2000, L18/1; Regulation (EC) No 1901/2006 of the European Parliament and of the Council of 12 December 2006 on medicinal products for paediatric use and amending Regulation (EEC) No 1768/92, Directive 2001/20/EC, Directive 2001/83/EC and Regulation (EC) No 726/2004, OJ 2006 L378/1; regulation (EC) No 1394/2007 of the European Parliament and of the Council of 13 November 2007 on advanced therapy medicinal products and amending Directive 2001/83/EC and Regulation (EC) No 726/2004, OJ 2006, L324/121.

${ }^{100}$ Council Directive 89/105/EEC of 21 December 1988 relating to the transparency of measures regulating the prices of medicinal products for human use and their inclusion in the scope of national health insurance systems, OJ 1989, L40/8. See Joined cases C-352/07 to C-356/07, C-365/07 to C-367/07 and C-400/07 A. Menarini Industrie Farmaceutiche Riunite Srl and Others $v$ Ministero della Salute and Agenzia Italiana del Farmaco (AIFA) (C-352/07), Sanofi Aventis SpA v Agenzia Italiana del Farmaco (AIFA) (C-353/07), IFB Stroder Srl v Agenzia Italiana del Farmaco (AIFA) (C-354/07), Schering Plough SpA v Agenzia Italiana del Farmaco (AIFA) (C-355/07), Bayer SpA v Agenzia Italiana del Farmaco (AIFA) and Ministero della Salute (C-356/07), Simesa SpA v Ministero della Salute and Agenzia Italiana del Farmaco (AIFA) (C365/07), Abbott SpA v Ministero della Salute and Agenzia Italiana del Farmaco (AIFA) (C-366/07), Baxter SpA v Agenzia Italiana del Farmaco (AIFA) (C-367/07) and SALF SpA v Agenzia Italiana del Farmaco (AIFA) and Ministero della Salute (C-400/07) [2009] ECR I-2495.

${ }^{101} \operatorname{COM}(2012) 84$ final, Proposal for a Directive of the European Parliament and of the Council relating to the transparency of measures regulating the prices of medicinal products for human use and their inclusion in the scope of public health insurance systems.

102 Council Directive 93/42/EEC of 14 June 1993 concerning medical devices, OJ 1993, L169/1.

${ }^{103}$ Council Directive 90/385/EEC of 20 June 1990 on the approximation of the laws of the Member States relating to active implantable medical devices, OJ 1990, L189/17.

${ }^{104}$ Directive 98/79/EC of the European Parliament and of the Council of 27 October 1998 on in vitro diagnostic medical devices, OJ 1998, L331/1.
} 
competing interests - and may prove influential on other products such as alcohol ${ }^{105}$ as the EU elaborates its interests further in these. Tobacco is governed in particular by the 2003 Tobacco Advertising Directive (TAD) discussed above and 2014 Tobacco Products Directive (TPD). The TPD is of particular note as challenges are ongoing with regard to the treatment of manufacturers of electronic cigarettes and the marketing of tobacco with characterizing flavours. ${ }^{106}$

The TPD repeals and updates a 2001 Directive,${ }^{107}$ which itself consolidated two previous Directives on tobacco labelling and tar yield. ${ }^{108}$ The TPD was deemed necessary ${ }^{109}$ in order to improve the functioning of the internal market by updating already harmonised areas so that Member States may increase the size of the health warnings, change their location of the package or replace the display of tar, nicotine and carbon monoxide levels. In addition the TPD was intended to address product-related measures, such as pictorial health warnings and regulation of ingredients in order to mitigate the heterogeneous development in Member States which may risk fragmentation of the internal market. Furthermore, the revision of the TPD focused on five policy areas: smokeless tobacco products and extension of the product scope, packaging and labelling, ingredients and additives, cross-border distance sales and traceability and security features.

The TPD takes as its legal basis Article 114 TFEU. This again appears to offer a source of potential conflict with the harmonisation prohibition of Article 168(5) TFEU, which - in contrast to Article 152(4)(c) EC - includes a specific reference to tobacco, although it was suggested in connection with the proposal for the TPD that too much should not be read into the exclusion. ${ }^{110}$ However, it is interesting to note, that although no explicit mention of Article 168(5) TFEU is made, challenges to the legality of the TPD, and in particular, the scope of Article 114 TFEU have already been advanced. ${ }^{111}$

105 Alemanno and Garde (2013) (n63).

106 Case C-358/14 Action brought on 22 July 2014 - Republic of Poland v European Parliament and Council of the European Union. Case C-477/14 Reference for a preliminary ruling from High Court of Justice Queen's Bench Division (Administrative Court) (England and Wales) (United Kingdom) made on 27 October 2014 - Pillbox 38 (UK) Limited, trading as 'Totally Wicked' v Secretary of State for Health. Case C-547/14 Reference for a preliminary ruling from the High Court of Justice, Queen's Bench Division (Administrative Court) (England and Wales) (United Kingdom) made on 1 December 2014 - Philip Morris Brands SARL, Philip Morris Limited, British American Tobacco UK Limited against Secretary of State for Health.

${ }^{107}$ Directive 2001/37/EC of the European Parliament and of the Council of 5 June 2001 on the approximation of the laws, regulations and administrative provisions of the Member States concerning the manufacture, presentation and sale of tobacco products.

${ }^{108}$ Directives 89/622 on tobacco labelling and 90/239/EEC on the maximum tar yield of cigarettes.

${ }^{109}$ European Commission, Proposal for a Directive of the European Parliament and of the Council on the approximation of the laws, regulations and administrative provisions of the Member States concerning the manufacture, presentation and sale of tobacco and related products. 2012/0366 (COD), Brussels,

19.12.2012. COM(2012) 788 final. Explanatory Memorandum.

${ }^{110}$ M.J.Elsmore and V.Obolevich, 'Thank you for not smoking: the Commission's proposal for a new Tobacco Products Directive - legally sound, but does it hit the spot?' European Law Review (2013), Issue 4, August 2013, 552-571.

${ }^{111}$ Case C-358/14 Action brought on 22 July 2014 - Republic of Poland v European Parliament and Council of the European Union. Case C-477/14 Reference for a preliminary ruling from High Court of Justice Queen's Bench Division (Administrative Court) (England and Wales) (United Kingdom) made on 27 October 2014 - Pillbox 38 (UK) Limited, trading as 'Totally Wicked' v Secretary of State for Health. Case C-547/14 Reference for a preliminary ruling from the High Court of Justice, Queen's Bench Division (Administrative Court) (England and Wales) (United Kingdom) made on 1 December 2014 - Philip Morris Brands SARL, Philip Morris Limited, British American Tobacco UK Limited against Secretary of State for Health. 


\section{EU policies}

Here we will only touch upon the two most important general EU policies that are related to the internal market but based on specific Treaty provisions that enable the EU to take legislative measures based on a Commission proposal and decision making by the European Parliament and the Council. These are health and safety at work and competition respectively.

\section{Health and safety at work}

Among the general EU legislation that has a significant practical impact on the healthcare sector is the Working time Directive. ${ }^{112}$ This is a health and safety at work measure (now under review) that has an exception inter alia for doctors in training. It has been much contested at national level because it effectively regulates the number of doctors and nurses who are required to adequately staff healthcare facilities. Thereby it has a major impact on the cost of healthcare provision, which in turn means it is politically sensitive.

\section{Competition}

The competition rules involve antirust, mergers and State aid. These are of increasing significance for healthcare.

\section{Definition of undertaking}

Whereas the free movement rules are targeted at public authorities, the competition rules apply exclusively to undertakings - although under certain conditions the Member States may infringe EU law by denying the competition rules their useful effect. This applies to the scope of antitrust (the prohibitions on cartels and dominance abuse) as well as to mergers and State aid. The latter concern advantages conferred by the Member States on specific undertakings. Because it determines whether the competition rules will be applicable or not, the definition of undertaking is obviously extremely important. ${ }^{113}$ However, because there is no statutory legal definition in EU law, the concept of undertaking has to be derived from the case law.

The 2001 Ambulanz Glöckner Case shows that any entity selling a product or service in a market under conditions of (in principle) competition should be considered an undertaking. ${ }^{114}$ In the 2000 Pavlov Case, the Court of Justice determined that even an individual medical practitioner could be regarded as an undertaking. ${ }^{115}$ Paradoxically (or even perversely) in FENIN (2006), it held that purchasing organisations of a national health service, even if operating in open markets themselves, should not be considered to be undertakings. ${ }^{116}$ Similarly in AOK Bundesverband (2004) the Court held that even

\footnotetext{
${ }^{112}$ Directive 2003/88/EC of the European Parliament and of the Council of 4 November 2003 concerning certain aspects of the organisation of working time, OJ 2003, L299/9. Case C-151/02 Landeshauptstadt Kiel v Norbert Jaeger [2003] ECR I-8389

${ }^{113}$ W. Sauter, 'The impact of EU competition law on national healthcare systems', European Law Review 38 (2013) 457-478; O. Odudu, 'The meaning of undertaking within Article 81 EC', Cambridge Yearbook of European Legal Studies 7 (2005) 209-239.

${ }^{114}$ Case C-475/99 Firma Ambulanz Glöckner v Landkreis Südwestpfalz. [2001] ECR I-8089.

115 Joined cases C-180/98 to C-184/98 Pavel Pavlov et al v Stichting Pensioenfonds Medische Specialisten [2000] ECR I-6451.

${ }^{116}$ Case C-205/03 P Federación Española de Empresas de Tecnología Sanitaria (FENIN) v Commission of the European Communities [2006] ECR I-6295.
} 
although price competition was in fact taking place the overall regulatory context meant that the German health insurance funds concerned were not undertakings. ${ }^{117}$

Such decisions possibly also reflect the political sensitivity of the healthcare sector at national level, which leads the EU courts to tread carefully. The AG2R Case (2011) in the context of health insurance suggests that aside from solidarity the degree of state supervision is likely to be decisive. ${ }^{118}$ Some further guidance is provided by Commission notices in the State aid context although confusingly the criteria supplied there differ from economic sector to sector. ${ }^{119}$ This also means that different criteria apply to health insurers and healthcare providers.

\section{Application of the antitrust rules}

In part due to the abovementioned difficulties of definition the application of the competition rules to the providers of healthcare services has not yet really taken off. ${ }^{120} \mathrm{~A}$ notable exception is the 2014 ONP Case which regarded an infringement by object of the cartel prohibition in Article 101 TFEU by a French association of pharmacists and clinical laboratories. ${ }^{121}$ At stake were the enforcement of minimum prices (one of the gravest cartel abuses) and foreclosure by blocking the formation of larger entities (group practices) within the sector.

\section{Pharmaceuticals cases}

By contrast with healthcare more generally, the antitrust rules have been applied extensively in the pharmaceuticals sector. In this sector there is an inherent tension between innovation and competition. There are three types of pharmaceuticals cases that are relevant here. These are: cases concerning (i) the blocking of parallel imports; (ii) abuse of procedure; and (iii) pay for delay cases. ${ }^{122}$ All three primarily involve the originator producers which hold the intellectual property rights on the active molecules (the substance with healing properties). The latter two types of case both regard their struggle against generics producers, copy-cat companies which can provide the same active ingredient at a fraction of the price once the intellectual property protection runs out and whose market entry consequently cuts costs for consumers.

Pharmaceutical producers practice price differentiation between the different Member States, a practice that is often considered beneficial on economic grounds - because (at least in some circumstances) it allows products to be offered to consumers who would

\footnotetext{
117 Joined cases C-264/01, C-306/01, C-354/01 and C-355/01 AOK Bundesverband, Bundesverband der Betriebskrankenkassen (BKK), Bundesverband der Innungskrankenkassen, Bundesverband der landwirtschaftlichen Krankenkassen, Verband der Angestelltenkrankenkassen eV, Verband der ArbeiterErsatzkassen, Bundesknappschaft and See-Krankenkasse v Ichthyol-Gesellschaft Cordes, Hermani \& Co. (C-264/01), Mundipharma GmbH (C-306/01), Gödecke $\mathrm{GmbH}(C-354 / 01)$ and Intersan, Institut für pharmazeutische und klinische Forschung GmbH (C-355/01), [2004] I-2493.

${ }^{118}$ Case C-437/09 AG2R Prévoyance v Beaudout Père et Fils SARL [2011] I-973.

${ }^{119}$ Communication from the Commission on the application of the European Union State aid rules to compensation granted for the provision of services of general economic interest, OJ 2012, C8/4; Draft Commission Notice on the notion of State aid pursuant to Article 107(1) TFEU, http://ec.europa.eu/competition/consultations/2014_state_aid_notion/draft_guidance_en.pdf ${ }^{120}$ J.W. van de Gronden and W. Sauter, 'Taking the temperature: EU competition law and healthcare', Legal Issues of European Integration 38 (2011) 213-241

${ }^{121}$ Case T-90/11 Ordre national des pharmaciens (ONP) et al. v Commission, Judgment of 10 December 2014.

${ }^{122}$ L. Hancher and W. Sauter, A dose of competition: EU antitrust law in the pharmaceuticals sector. TILEC Discussion Paper No. 2015-017.
} 
otherwise be priced out of the market. To protect price differentiation, parallel imports are blocked by originator producers to in order to bar wholesalers in low price Member States (say Greece) from re-exporting pharmaceutical products to high price Member States (say Germany). This practice is considered to be an abuse of Articles 101 and/or 102 TFEU. ${ }^{123}$

Abuse of procedure involves originating producers using the fragmented nature of the patent and market authorization rules within the EU to hoodwink regulatory authorities into extending protection of their products and strategically withdrawing information and production formats that generics producers could have used to enter the market. ${ }^{124}$ 'Pay for delay' finally concerns cases where originator producers bribe generics producers not to enter the market (or in any event to delay their entry), in effect splitting their monopoly rents at the expense of consumers as well as insurers and/or public purchasers. ${ }^{125}$

\section{State aid and SGEI}

The State aid rules apply where an undertakings enjoys a (selective) advantage that is granted from state resources and has an effect on trade, ${ }^{126}$ as well as on competition. Once the existence of an aid is established, the Commission has exclusive jurisdiction on whether to declare the aid concerned compatible with the internal market. The relevant procedure has two phases, based on the existence or absence of serious doubts established in the first phase, the second phase (which is involves an in-depth investigation) is initiated. With regard to compensation paid for public services, ever since the 2003 Altmark case the focus has been on the concept of advantage: where the service offered is simply a quid pro quo the State aid rules do not apply. ${ }^{127}$ This rule has been elaborated by

${ }^{123}$ On Art 101 TFEU see: Joined cases C-501/06 P, C-513/06 P, C-515/06 P and C-519/06 P GlaxoSmithKline Services Unlimited v Commission of the European Communities $(C-501 / 06 P)$ and Commission of the European Communities v GlaxoSmithKline Services Unlimited (C-513/06 P) and European Association of Euro Pharmaceutical Companies (EAEPC) v Commission of the European Communities (C-515/06 P) and Asociación de exportadores españoles de productos farmacéuticos (Aseprofar) v Commission of the European Communities (C-519/06 P) [2009] ECR I-9291. On Art 102 TFEU see: Joined Cases C-468/06 to C-478/06 Sot. Lelos kai Sia EE (C-468/06), Farmakemporiki AE Emporias kai Dianomis Farmakeftikon Proionton (C-469/06), Konstantinos Xidias kai Sia OE (C-470/06), Farmakemporiki AE Emporias kai Dianomis Farmakeftikon Proionton (C-471/06), Ionas Stroumsas EPE (C-472/06), Ionas Stroumsas EPE (C-473/06), Farmakapothiki Farma-Group Messinias AE (C-474/06), K.P. Marinopoulos AE Emporias kai Dianomis Farmakeftikon Proionton (C-475/06), K.P. Marinopoulos AE Emporias kai Dianomis Farmakeftikon Proionton (C-476/06), Kokkoris D. Tsanas K. EPE and Others (C-477/06), Kokkoris D. Tsanas K. EPE et al. (C-478/06) v GlaxoSmithKline AEVE Farmakeftikon Proionton, formerly Glaxowellcome AEVE [2008] ECR I-7139. L.G. Grigoriadis, 'The application of EU competition law in the pharmaceutical sector: the case of parallel trade', European Business Law Review 25 (2014 ) 141-201.

${ }^{124}$ Case C-457/10 P AstraZeneca AB and AstraZeneca plc v Commission, Judgment of 6 December 2012. ${ }^{125}$ Commission Decision of 19 June 2013 addressed to - Lundbeck Limited - H. Lundbeck A/S - Generics [UK] Limited - Merck KGaA - Arrow Generics Limited - Arrow Group ApS - Resolution Chemicals Limited - Xellia Pharmaceuticals ApS - Zoetis Products LLC - A.L. Industrier AS - Ranbaxy (U.K.) Limited - Ranbaxy Laboratories Limited relating to a proceeding under Article 101 of the Treaty on the Functioning of the European Union and Article 53 of the EEA Agreement (AT.39226 - Lundbeck); Commission Decision of 10 December 2013 addressed to - Johnson \& Johnson, Janssen-Cilag B.V.,Novartis AG,- Sandoz B.V. relating to a proceeding under Article 101 of the Treaty on the functioning of the European Union (AT.39685 - Fentanyl). Case AT.39612 - Perindopril (Servier). O. Gurgula, 'Restrictive practices in pharmaceutical industry: reverse payment agreements. Seeking for a balance between intellectual property and competition law', Global Antitrust Review 4 (2012) 58-104.

${ }^{126}$ Commission Decision in case N 543/2001 - Ireland - Capital allowances for hospitals, OJ 2002, C $154 / 3$.

${ }^{127}$ Case C-280/00 Altmark Trans GmbH and Regierungspräsidium Magdeburg v Nahverkehrsgesellschaft Altmark GmbH, and Oberbundesanwalt beim Bundesverwaltungsgericht [2003] ECR I-7747. 
the Commission in a package of legislation which sets the terms for those cases where the Altmark requirements are not fully met (notably the efficiency requirement) so there is aid but where the aid concerned is compatible with the internal market. This is known as the Altmark package, published in 2005 and recast in $2012 .{ }^{128}$

As part of the Altmark package special rules are set for hospitals and long term care providers in a Commission Decision of 2012 that works as a block exemption. ${ }^{129}$ Their financing is regarded as compatible with the internal market without need of an individual notification to the Commission provided they are subject to an act of entrustment setting out public service tasks, receive only the compensation that is necessary to these tasks and with a system to control for overcompensation (note the absence of an efficiency requirement). An example of their application is the Commission's IRIS-H decision on the financing of public hospitals in the Brussels region (2014). In this case, following the 2012 annulment by the General Court of an initial (first phase) Commission decision to declare the aid compatible, ${ }^{130}$ the Commission decided to open second phase investigations with regard to potential overcompensation. ${ }^{131}$

\section{Mergers}

Because so far healthcare services and financing are organized predominantly along national lines, mergers across borders within the EU have been rare. Hence, we will not go into detail on this topic, which has so far been relevant mainly to a handful of mergers of producers of pharmaceutical products and of medical devices, and a small number of hospital mergers.

\section{Governance and healthcare}

Thus far we have considered the history of EU health law and policy and how its scope has expanded by reference to the involvement of the EU institutions (most obviously the Commission and the Court of Justice) and the legal basis as provided by Article 168 TFEU and the Treaty provisions governing the internal market. This has revealed two fundamental sources of tension in respect of the development of EU health law and policy: regarding the respective competence of the formal EU institutions and Member States on the one hand (particularly in view of Article 168(7) TFEU) and between 'economic', 'social' and 'health' actors ${ }^{132}$ within the wider EU architecture on the other. The latter enables two 'faces' of health policy to be identified: public health aspects and internal market law. ${ }^{133}$ This raises the further question of whether healthcare is indeed separate, or whether it can be adequately incorporated within wider 'economic' and 'social' policies.

\section{New modes of governance}

\footnotetext{
${ }^{128}$ W. Sauter, 'The Altmark package Mark II: New rules for state aid and the compensation of services of general economic interest', European Competition Law Review 33 (2012) 307-313.

${ }^{129}$ Commission Decision of 20 December 2011 on the application of Article 106(2) of the Treaty on the Functioning of the European Union to State aid in the form of public service compensation granted to certain undertakings entrusted with the operation of services of general economic interest, OJ 2012, L7/3. ${ }^{130}$ Case T-137/10 CBI v Commission, Judgment of 7 November 2012.

${ }^{131}$ SA.19864 Public financing of Brussels public IRIS hospitals, Decision of 14 October 2014. L. Hancher and W. Sauter, ' This won't hurt a bit: the Commission's approach to services of general economic interest and state aid to hospitals', in J.W. van de Gronden and E. Szyszczak (eds), Financing SGEI: State Aid Reform and Modernisation (TMC Asser Press, The Hague 2013), 249-272

${ }^{132}$ S L Greer and B Vanhercke, 'The hard politics of soft law: the case of health', chapter 4 in eds.

Mossialos et al. (2010) (n1).

${ }^{133}$ Greer (2014) (n88).
} 
Our consideration thus far has focused on the 'classic community method' of governance, premised upon the Commission's exclusive right of legislative initiative and of harmonising legislation. This method has been deemed has been limited in its contribution to EU competence regarding health, ${ }^{134}$ and offers a primary explanation in the use of new governance mechanisms by the EU institutions in the healthcare field. ${ }^{135}$

Consequently, over the past twenty years, there has been varying degrees of emphasis on what have been termed 'new modes of governance', as distinct from the rigid framework perceived to be offered by the hierarchies and norms associated with the community method. It is evident that the involvement of the Commission and the Court has not disappeared in the interim, so it would be incorrect to suggest that new governance instruments have supplanted these. Rather, the new instruments might be considered complementary as they have been introduced to assist implementation of wider EU policies (such as the Lisbon and Europe 2020 Strategies) which might include healthrelated aspects, but health does not represent a main focus. Although 'new governance' is difficult to define, more 'healthcare-specific' examples might include The Platform on diet, nutrition and physical activity and The High Level Group on Health Services and Medical Care. ${ }^{136}$

Questions therefore arise as to whether and how these new modes of governance may determine the scope of EU health law and policy. Certainly the tensions identified thus far - regarding the respective competence of the Commission and the Member States and the respective 'economic' or 'social' focus - appear relevant to a discussion of new governance. Indeed, it has been suggested that if the formal institutions of the EU are to operate according to the Community method, they must regard healthcare not as healthcare but as something else (probably the single internal market). ${ }^{137}$ It appears pertinent to ask whether new governance instruments also regard healthcare as healthcare, or as something else - perhaps a single aspect among several in ensuring wider financial sustainability.

Both institutions and governance arrangements of EU health law and policy, and EU economic governance of health systems will be considered in more detail in subsequent contributions. We therefore set the scene here for these further discussions with brief overviews of how the Open Method of Coordination (OMC) and the European Semester have been related to healthcare, thus may influence the scope of EU health law and policy. These two instruments have been chosen as representing two significant wider EU growth strategies: the Lisbon Strategy, which aimed to make the EU 'the most competitive and dynamic knowledge-driven economy by 2010 ', ${ }^{138}$ and Europe 2020, which aims to deliver smart, sustainable and inclusive growth. ${ }^{139}$ These provide a useful framework in determining the scope of EU health law and policy and perhaps indicate the

\footnotetext{
${ }^{134}$ See on this point, inter alia, Greer and Vanhercke (2010) (n132), T Hervey and B Vanhercke, 'Health care and the EU: the law and policy patchwork', chapter 2 in eds. Mossialos et al. (2010) (n1).

${ }^{135} \mathrm{~T}$ K Hervey, 'The European Union's governance of health care and the welfare modernization agenda', Regulation \& Governance (2008) 2, 103-120.

${ }^{136}$ As discussed by Greer and Vanhercke (2010) (n134), p.194-5.

137 Ibid.

${ }^{138}$ Presidency Conclusions, Lisbon European Council, 23 and 24 March 2000, http://www.consilium.europa.eu/en/uedocs/cms_data/docs/pressdata/en/ec/00100-r1.en0.htm

${ }^{139}$ European Commission, 'Europe 2020', http://ec.europa.eu/europe2020/europe-2020-in-anutshell/priorities/index_en.htm
} 
direction of travel, as well as bringing its history up to date for the purposes of this contribution.

\section{The OMC and healthcare}

In general terms, the OMC was established by the Maastricht Treaty as an instrument destined for coordinating national economic policies through the use of recommendations and guidelines. ${ }^{140}$ In practical terms, the 'OMC toolbox' has been described as typically comprising joint (EU) objectives (political priorities), indicators, guidelines and sometimes targets; national reports or action plans to assess performance against objectives and metrics; peer review of national plans through mutual criticism and exchange of good practices. ${ }^{141}$

As regards the conception of the OMC as a tool to develop the scope of EU health law and policy, at least two considerations should be borne in mind: the relationship between the OMC (developed originally in the context of employment) and healthcare themes, and the scope for the OMC to influence the development of policy at EU and national levels.

\section{OMC as a general tool}

Firstly, it should be recalled that the OMC, along with other new modes of governance, has been generalised to the healthcare sector. ${ }^{142}$ It was thus not designed as a "healthcarespecific' policy tool, which perhaps lends support to the view that healthcare does not represent a special case. Rather, a 'healthcare' OMC was introduced in 2004, ${ }^{143}$ following OMCs relating to social inclusion and pensions - the OMC in the field of social protection having emerged in 1999 in response to the EU's economic integration. ${ }^{144}$ Thus healthcare appears to be regarded in the wider context of social policy, consistent with the conception of this as a counterbalance to the existence of economic growth as an EU objective under the Lisbon Strategy.

This view is consolidated by the streamlining in 2006 of the three social OMCs into a single, overarching process - the Social OMC - with both common and sector-specific objectives following the relaunch of the Lisbon Strategy in $2005 .{ }^{145}$ The Social OMC stipulated common objectives for Member States which emphasized accessibility and affordability of adequate and high-quality health and long-term care. ${ }^{146}$ It has been noted

${ }^{140}$ B Kohler-Koch and B Rittberger, 'Review Article: The 'Governance Turn' in EU Studies', JCMS 2006 Volume 44 Annual Review, pp.27-49.

${ }^{141}$ Hervey and Vanhercke (2010) (n136).

${ }^{142}$ Greer and Vanhercke (2010) (n134).

${ }^{143}$ Commission of the European Communities, 'Communication from the Commission to the Council, the European Parliament, the European Economic and Social Committee and the Committee of the Regions: Modernising social protection for the development of high-quality, accessible and sustainable health care and long-term care: support for the national strategies using the 'open method of coordination'. Brussels, 20.4.2004, COM(2004) 304 final.

${ }^{144}$ R Baeten and S Thomson, 'Health care policies: European debate and national reforms' in eds. D Natali and B Vanhercke, 'Social Developments in the European Union 2011', Thirteenth Annual Report, European Trade Union Institute (ETUI) and European Social Observatory (OSE).

${ }^{145}$ For a brief discussion, see J Zeitlin and B Vanhercke, 'Socializing the European Semester? Economic Governance and Social Policy Coordination in Europe 2020' Swedish Institute for European Policy Studies (SIEPS), Report No. 7, December 2014.

${ }^{146}$ European Commission, 'Joint Report on social protection and social inclusion 2007: social inclusion, pensions, healthcare and long-term care', Directorate-General for Employment, Social Affairs and Equal Opportunities (2007), p.83. Discussed in Greer and Vanhercke (2010) (n134), Box 4.2 'Common objectives with regard to health care', page 207; and Baeten and Thomson (2011) (n146), Box 2 'Common objectives for health and long-term care in the Social OMC', page 196. 
that the content of these objectives not only closely resemble the health system goals set out by the World Health Organization. ${ }^{147}$ It seems clear that healthcare in the context of the Social OMC is being defined by reference to other, typically economic aims, as opposed to public health matters as demonstrated by Article 168 TFEU, or other healthrelated concerns. However, it has been suggested ${ }^{148}$ that the Commission considered expanding application of OMC-type processes to areas such as organ donation and transplantation, nanosciences and nanotechnologies and even e-health. ${ }^{149}$

Secondly, as regards the actors involved in the OMC, it would appear that attempts were made to weight the balance in favour of Member States, which would appear to constrain the scope for input by formal EU institutions, specifically the Commission. This has been inferred from the 2004 'healthcare' OMC being launched with a provisional institutional architecture, an explicit lack of enthusiasm on the part of the Social Affairs Council and by ministers for health opting to vest control of the European healthcare agenda in the Council. ${ }^{150}$ However, there are at least two aspects which appear to question the Member States' enthusiasm for, and ability to exert control over the OMC process which are now considered.

\section{Limitations of OMC}

On the one hand, the Social OMC is described as 'a voluntary process for political cooperation based on agreeing common objectives and measuring progress towards these goals using common indicators', which involves the Commission working together with Member States through the Social Protection Committee and cooperating with stakeholders, including Social Partners and civil society. ${ }^{151}$ The voluntary nature of the process is both the price the Commission has to pay to secure Member State involvement, and a potential step along the way to a moral, and thus de facto obligation. ${ }^{152}$

On the other hand, it has been suggested that the application of the OMC to healthcare remains contentious especially in view of measuring health systems' performance as, in view of the sensitivity attached to healthcare, governments' self-confidence and openness to learning from each other and trying to resolve problems commonly is quite low in this policy field. ${ }^{153}$ Despite this, it has been suggested that there may be distinctions to be drawn between the relative availability of reliable empirical evidence of the practical effects of OMC in healthcare in the 'old' member states, which are less are less enthusiastic about decisions on 'health' being taken at EU level than 'newer' member states (in central and eastern Europe), which lack evidence as they continue to 'catch up' in healthcare as well as other areas. ${ }^{154}$

\footnotetext{
${ }^{147}$ See Baeten and Thomson (2011) (n146)Box 2.

148 Greer and Vanhercke (2010) (n134), p.197.

${ }^{149}$ European Commission, 'Organ donation and transplantation: policy actions at EU level', COM (2007) 275 final, 30 May 2007, page 10. European Commission, 'Nanosciences and nanotechnologies: an action plan for Europe 2005-2009', COM (2005) 243 final, 7 June 2005, p.4. European Commission, 'Making healthcare better for European citizens: an action plan for a European e-health area', COM (2004) 356 final, 30 April 2004, p.16.

${ }^{150}$ Greer and Vanhercke (2010) (n134), p.204-5.

${ }^{151} \mathrm{http}: / /$ ec.europa.eu/social/main.jsp?catId=750.

${ }^{152}$ W Lamping, 'EU health care policy', Chapter 2 in eds. S L Greer and P Kurzer, 'European Union Public Health Policy - Regional and Global Trends', Routledge 2013. P.28-9

${ }^{153}$ Ibid.

154 Ibid.
} 
The foregoing arguably suggests that while various attempts have been made to elaborate the OMC vis-à-vis healthcare, what it can achieve due to its voluntary nature, and indeed has achieved, in practical terms remains unclear. It has been considered that under the Europe 2020 strategy, the role of the Social OMC, including healthcare, seems to have been weakened. ${ }^{155}$

\section{The European Semester and healthcare}

\section{Overview of the European Semester}

In very general terms, ${ }^{156}$ the European Semester is an annual review process which implements the 2011 and 2013 reforms ${ }^{157}$ of the Stability and Growth Pact (SGP) made possible by the global financial crisis. These reforms instituted a wide-ranging regime of economic and budgetary monitoring and assessment with preventive and corrective elements underpinned, inter alia, by Treaty provisions. ${ }^{158}$ The European Semester also enables the Commission to review information pertinent to strategies such as the Euro Plus Pact and Europe 2020, so has therefore been considered a powerful tool for achieving consistent policy recommendations among Member States as well as horizontally across EU and European programmes. ${ }^{159}$

In addition, it offers a vital link between the soft-law style of target setting often associated with the EU's new governance programmes, such as Europe 2020, and the harder structural adjustment politics of the EU's economic crisis. ${ }^{160}$ Furthermore, by beginning with budgetary discipline and structural adjustment issues, which have a legal basis in the TFEU and a normative basis in ECFIN, the European Semester exists as a framework that can impose its hierarchy on other, non-economic policy areas, thus social and environmental policy governance. ${ }^{161}$

\section{Does the European Semester influence the scope of EU health policy?}

\footnotetext{
${ }^{155}$ Baeten and Thomson (2011) (n146).

156 For a comprehensive overview, see Greer et al (2014) (n1), Chapter 5, 'Fiscal governance and what it means for health systems'.

${ }^{157}$ Which resulted in rafts of guidance known as the 'six pack' and the 'two pack'. The 'six pack' relates to the 2011 reforms and comprises European Parliament and Council Regulation (EU) No. 1175/2011 of 16 November 2011 amending Council Regulation (EC) No 1466/97 on the strengthening of the surveillance of budgetary positions and the surveillance and coordination of economic policies; Council Regulation (EU) No 1177/2011 of 8 November 2011 amending Regulation (EC) No 1467/97 on speeding up and clarifying the implementation of the excessive deficit procedure; Regulation (EU) No 1173/2011 of 16 November 2011 on the effective enforcement of budgetary surveillance in the euro area; Council Directive 2011/85/EU of 8 November 2011 on requirements for budgetary frameworks of the Member States; Council Directive 2011/85/EU of 8 November 2011 on requirements for budgetary frameworks of the Member States; Regulation (EU) No 1176/2011 of 16 November 2011 on the prevention and correction of macroeconomic imbalances. The 'two pack' relates to the 2013 reforms and comprises European Parliament and Council Regulation (EU) No 473/2013 on common provisions for monitoring and assessing draft budgetary plans and ensuring the correction of excessive deficit of the member states in the euro area; Regulation 472/2013 on the strengthening of economic and budgetary surveillance of member states in the euro area experiencing or threatened with serious difficulties with respect to their financial stability.

158 Article 121 TFEU establishes the preventive arm, and Article 126 TFEU the corrective arm in connection with the Excessive Deficit Procedure (EDP). In contrast, the six-pack is enshrined by the Treaty on Stability, Coordination and Governance in the Economic and Monetary Union (TSCG), a non-EU international treaty. See Greer et al. (2014) (n1).

${ }^{159}$ Greer et al (2014) (n1).

${ }^{160}$ Ibid.

${ }^{161}$ Ibid.
} 
Thus far, the European Semester appears to reinforce two of the tensions previously identified in connection with the scope of EU health policy, namely, the respective competence of the EU and Member States, and explicit recognition (or not) of healthcare as a special case.

Whilst healthcare may not feature explicitly in these mechanisms (for instance as a Europe 2020 target), it should be noted that country-specific recommendations (CSRs) regarding healthcare have been formulated within the European Commission and extended to Member States in the context of the European Semester since $2012^{162}$ and have increased and expanded in the intervening years. ${ }^{163}$ These CSRs have related to, for example, the strengthening of national budgetary frameworks, or improving the long-term sustainability of public finances. ${ }^{164}$ They have included general advice to curb health expenditure and increasing cost-effectiveness of the healthcare sector as well as specific recommendations in 2013 to reduce 'inappropriate' lengths of stay in hospitals in the Czech Republic, and to improve integration of care delivery and focus more strongly on rehabilitation and independent living in Germany. ${ }^{165}$ It is notable that the CSRs have been extensive in terms of country coverage: Denmark, Sweden and the UK are the only EU Member States not to receive a CSR on health or long-term care. ${ }^{166}$

Furthermore, each Annual Growth Summary (AGS) drawn up in connection with the European Semester has stressed improvement in cost efficiency and financial sustainability of national healthcare systems with an eye to improving balance in public spending. ${ }^{167}$ In addition, as a response to the increasing social consequences of the economic and financial crisis and the increasing criticism that EU management's onesided focus on the budgetary and economic aspects, various initiatives have been taken to strengthen the social dimension of the European Semester. ${ }^{168}$ Although healthcare features among these, it does so to a lesser extent than other aspects of social policy. ${ }^{169}$ In addition, despite the focus on Member State activity attached to the CSRs, an absence of national input into the European Semester process has been recognised. ${ }^{170}$

What is particularly interesting about these two aspects is the extent to which they may be considered to refocus EU health law and policy. In particular, both may appear to suggest contradictions in respect of EU competence vis-à-vis Article 168(7) TFEU regarding the delivery of national healthcare systems. In contrast to the Social OMC, characterized by uncontroversial objectives, what we are now seeing are, for example, the EU-IMF Memoranda of Understanding signed with Greece, Ireland and Portugal which go beyond objectives, guidance or recommendations to take the form of detailed instructions for health system reform that are subject to quarterly review and sanctions for noncompliance. ${ }^{171}$ Indeed, as financial instruments have the most coercive effect in

\footnotetext{
${ }^{162}$ For a thorough explanation of the process and actors involved, see R Baeten and D Ghailani, "Beleid en recht van de Europese Unie: ontwikkelingen die het nationale gezondheidszorgbeleid beïnvloeden', Observatoire social européen Briefing Paper Nr.10/April 2015.

163 Ibid, pages 9-10.

${ }^{164}$ See European Commission, 'European Semester 2014'. See Greer et al (2014) (n1) p.124.

${ }^{165}$ For an overview of CSRs made to Member States between 2011-2013, see Greer (2014), p.124-5. Baeten and Ghailani (2015) (n164) include 2014 in their assessment - p.11. (FN12 for Commission website).

${ }^{166}$ Greer et al. (2014) (n1).

${ }^{167}$ Baeten and Ghailani (2015) (n164).

168 Ibid, p. 21.

169 Ibid.

${ }^{170}$ Ibid, page 17.

${ }^{171}$ Baeten and Thomson (2011) (n146), p.198.
} 
implementing recommendations, compliance appears most evident in countries subject to an economic adjustment programme (such as Greece and Romania), or who rely on financial support of the European Structural Funds (typically most of the newer Member States). ${ }^{172}$ A potential consequence of this is that the European Semester can become an instrument for the 'richer' Member States to compel restructuring in 'poorer' Member States, rather than a process whereby the European Commission strengthens its grip on national healthcare policy. ${ }^{173}$

However, alongside the above developments regarding fiscal governance, it should be noted that there have also been initial steps towards what has been termed an 'EU agenda for healthcare reform', comprising a 'thought process' started by the Council of Health Ministers in 2011 to help Member States develop modern, adaptable and sustainable healthcare systems.

\section{Conclusion}

The healthcare sector is of high political and social importance in all EU Member States. Hence they tend to guard their sovereignty in this sphere strongly. We have shown above how nevertheless over time the force of the internal market and competition rules has gradually been extended to healthcare (opening the road for the adoption of the Patients' Rights Directive). So have the exceptions to these rules (such as in the context of SGEI). At the same time new forms of cooperation and healthcare specific competencies have opened up, and general legal and economic trends, including in terms of governance (such as OMC and the European Semester) have impacted healthcare.

The various subsections of Article 168 TFEU demonstrate that while EU competence in the field of public health might be expanding, there are undoubtedly limits to its scope, defined most obviously in terms of a prohibition on harmonisation and renewed emphasis on subsidiarity. It is also evident that aspects found in other areas of EU law, particularly regarding forms of governance, are also found in health, which could lead to the conclusion that health is not a special case. Indeed, it appears that Article 168 TFEU is tightly circumscribed ${ }^{174}$ and that explicit Treaty articles authorising the EU to enact measures affecting health are only a subordinate element of EU health law and policy. ${ }^{175}$

However, the emphasis on the subsidiarity principle implicit in Article 168 TFEU can be questioned in light of Commission statements such as ' $(\mathrm{H})$ ealthcare systems need to be reformed to provide quality healthcare through efficient structures, including eHealth'. ${ }^{176}$ Indeed, the emergence of new forms of governance has been considered to challenge the binary distinction between national and EU competence. ${ }^{177}$ However, while health system reform in some Member States is clearly linked to economic agreements in the context of the European Semester, in others it is not. For example, it is difficult to equate recent legislation intended to entrench competition in the English NHS with economic

\footnotetext{
${ }^{172}$ Baeten and Ghailani (2015) (n164).

${ }^{173}$ Ibid.

${ }^{174}$ Although this, and other aspects of health law and policy may be wider in scope in light of the potential role for the CJEU in this area, which has thus far received less attention. For a discussion of this, see E. Brooks, 'Crossing borders: A critical review of the role of the European Court of Justice in EU health policy', Health Policy 105 (2012) 33-37.

175 Greer, Hervey, Mackenbach, McKee (2013) (n1).

${ }^{176}$ European Commission, 'European Semester Thematic Fiche: Health and Health Systems'.

177 Hervey and Vanhercke (2010) (n134).
} 
agreements at EU level - rather, it might be considered that such reforms have been constrained by CJEU case law in this area.

In addition, as we have seen, there have been significant changes in approach with regard to health policy at EU level via the Social OMC and the CSRs and other recommendations arising out of the European Semester Process. However, the extent to which the financial crisis ${ }^{178}$ prompted the EU's shift in policy is contentious: it has been suggested that this merely created a window of opportunity for the EU to claim greater influence over an aspect of national competence. ${ }^{179}$ In this view, the Commission is using economic actors and institutional mechanisms where EU competence is less contested, to communicate and progress its policies on healthcare - an area where it does not have a clear competence. ${ }^{180}$

Consequently our reading of the answers to the three questions set out in the introduction is as follows:

First, is the competence of the EU in the area of health law and policy expanding, and if so, in which directions? Formal competences remain largely the same, in fact have been restricted further in successive Treaty amendments. However EU involvement in healthcare appears to be expanding in all directions, most recently including core issues such patients' rights to reimbursement and regarding the financial sustainability of healthcare funding in the context of the European semester.

Second, are there clear and fixed limits to its scope? The limits are fixed primarily by Article 168 TFEU and have been clarified by the Court of Justice on a number of occasions, notably the Tobacco Cases. An important qualification is that harmonization legislation that touches upon the area of healthcare is not foreclosed by the existence of Article 168 TFEU. This allows Article 114 TFEU to be used, albeit sometimes in combination with Article 168 TFEU (as for the patients' rights Directive).

Third, to what extent is healthcare law and policy a special case and to what extent do general trends in EU integration play a role here? Healthcare is a special case in terms of the strenuous efforts that the Member States have made to retain control over their national systems. Nevertheless general trends in EU integration clearly have an impact, such (i) mutual recognition and completion of the internal market, (ii) the emergence of patients' and/or citizens' rights and more recently (iii) that of fiscal probity and the European semester.

In sum: in spite of national efforts to retain control over healthcare, such control is in fact steadily eroded. The result however is less the emergence of a unified EU policy than a complex system of partial overlapping national and EU competences that at various points both come into conflict and complement each other. Overall the net effect is an increasing impact of EU policies on healthcare even in what for the foreseeable future will be the absence of an EU policy on health.

\footnotetext{
${ }^{178}$ Apparently considered by Greer to create a third 'face' of EU health policy. See Greer (2014) (n88).

${ }^{179}$ See Baeten and Thomson (2011) (n146).

${ }^{180}$ A de Ruijter and T Hervey, 'Healthcare and the Lisbon Agenda' in (eds) P Copeland and D Papadimitriou, 'Ten Years of the EU's Lisbon Agenda', Palgrave, Macmillan 2012 cited in Baeten and Thomson (2011) (n146).
} 